\title{
Differentiation of Mammalian Vestibular Hair Cells from Conditionally Immortal, Postnatal Supporting Cells
}

\author{
Patrick Lawlor, Walter Marcotti, Marcelo N. Rivolta, Corné J. Kros, and Matthew C. Holley \\ Department of Physiology, School of Medical Sciences, University of Bristol, Bristol, BS8 1TD, United Kingdom
}

\begin{abstract}
We provide evidence from a newly established, conditionally immortal cell line (UB/UE-1) that vestibular supporting cells from the mammalian inner ear can differentiate postnatally into more than one variant of hair cell. A clonal supporting cell line was established from pure utricular sensory epithelia of $\mathrm{H} 2 \mathrm{k}^{\mathrm{b}}$ ts $\mathrm{A} 58$ transgenic mice $2 \mathrm{~d}$ after birth. Cell proliferation was dependent on conditional expression of the immortalizing gene, the "T" antigen from the SV40 virus. Proliferating cells expressed cytokeratins, and patch-clamp recordings revealed that they all expressed small membrane currents with little time-dependence. They stopped dividing within $2 \mathrm{~d}$ of being transferred to differentiating conditions, and within a week they formed three defined populations expressing membrane currents characteristic of supporting cells and two kinds of neonatal hair cell. The cells expressed several characteristic fea-
\end{abstract}

tures of normal hair cells, including the transcription factor Brn3.1, a functional acetylcholine receptor composed of $\alpha 9$ subunits, and the cytoskeletal proteins myosin VI, myosin VIIa, and fimbrin. Immunofluorescence labeling and electron microscopy showed that the cells formed complex cytoskeletal arrays on their upper surfaces with structural features resembling those at the apices of normal hair cells. The cell line UB/UE-1 provides a valuable in vitro preparation in which the expression of numerous structural and physiological components can be initiated or upregulated during early stages of mammalian hair cell commitment and differentiation.

Key words: mouse; vestibular; utricle; hair cells; epithelial cells; conditional immortalization; tsA58; differentiation; development; potassium current; inward rectifier
Most mechanosensory epithelia are composed of sensory hair cells surrounded by nonsensory supporting cells. Hair cells can be replaced in many vertebrate epithelia, including those from fish (Presson and Popper, 1990; Presson, 1994), amphibia (Baird et al., 1996), and birds (Corwin and Cotanche, 1988; Ryals and Rubel, 1988) (for review, see Cotanche et al., 1994; Stone et al., 1998). There is little evidence that mammalian auditory hair cells can be replaced after birth (Kelley et al., 1993, 1995; Lefebvre et al., 1993; Chardin and Romand, 1995; Forge et al., 1998) but convincing evidence for a low level of hair cell replacement in mammalian vestibular organs (Forge et al., 1993; Warchol et al., 1993). Cell lineage studies in the chick show that hair cells and supporting cells share a common precursor (Fekete et al., 1998), and selective ablation of hair cells in fish lateral line reveals that supporting cells can replace hair cells during sensory regeneration (Jones and Corwin, 1996).

The mammalian inner ear possesses just a few thousand sensory cells that are encased in several layers of bone and show little proliferative activity in vitro. Thus there has been some effort to establish mammalian cell lines that will enable more controlled studies of the mechanisms of cell differentiation and regeneration (Barald et al., 1997; Holley et al., 1997; Rivolta et al., 1998; Zheng et al., 1998). The utricular macula provides a good model for mammalian mechanosensory epithelia because it retains the abil-

\footnotetext{
Received June 8, 1999; revised Aug. 4, 1999; accepted Aug. 13, 1999.

This work was supported by The Wellcome Trust. M.C.H. is a Royal Society University Research Fellow.

P.L. and W.M. contributed equally to this work.

Correspondence should be addressed to Matthew C. Holley or Corné J. Kros, Department of Physiology, School of Medical Sciences, University of Bristol, University Walk, Bristol BS8 1TD, UK. E-mail: m.c.holley@bristol.ac.uk or c.j.kros@bristol.ac.uk.

Copyright (C) 1999 Society for Neuroscience $\quad 0270-6474 / 99 / 199445-14 \$ 05.00 / 0$
}

ity to replace hair cells postnatally. It is also conveniently composed of a simple layer of hair cells and supporting cells that can be separated enzymatically from the underlying connective tissue (Saffer et al., 1996).

Our hypothesis was that mammalian neonatal utricular supporting cells retain the potential to differentiate into hair cells. To establish conditionally immortal cells as close as possible to the developmental stage at dissection, we used the H2k $\mathrm{k}^{\mathrm{b}}$ s A58 transgenic mouse (Immortomouse) as a source of differentiating cells (Jat et al., 1991; Rivolta et al., 1998). During early stages of development, utricular epithelial cells normally express cytokeratins and vimentin (Kuijpers et al., 1992). In differentiated hair cells, both proteins are expressed at lower levels, with cytokeratin almost absent, but in supporting cells cytokeratin expression remains high. Specific markers for hair cells include the transcription factor Brn3.1 (Erkman et al., 1996; Xiang et al., 1997), the $\alpha 9$ subunit of the acetylcholine receptor (Elgoyhen et al., 1994; Glowatzki et al., 1995), an isoform of the cytoskeletal protein fimbrin (Lee and Cotanche, 1996; Slepecky, 1996), and the motor proteins myosin VI and VIIa (Hasson et al., 1997). Supporting cells express relatively small basolateral membrane currents (Sugihara and Furukawa, 1996; Masetto and Correia, 1997), whereas different types of hair cell express large characteristic outward and/or inward rectifier currents (Rüsch et al., 1998). We selected immortal cell lines expressing cytokeratins to confirm their identity as supporting cells and then assessed them under differentiating conditions using both structural and physiological markers for the different cell types.

\section{MATERIALS AND METHODS}

Isolation and culture of cell lines. Four epithelial sheets from the utricular maculae were dissected from the ears of Immortomouse pups at postnatal day 2 (P2). After the nonsensory epithelium and the outer margins of 

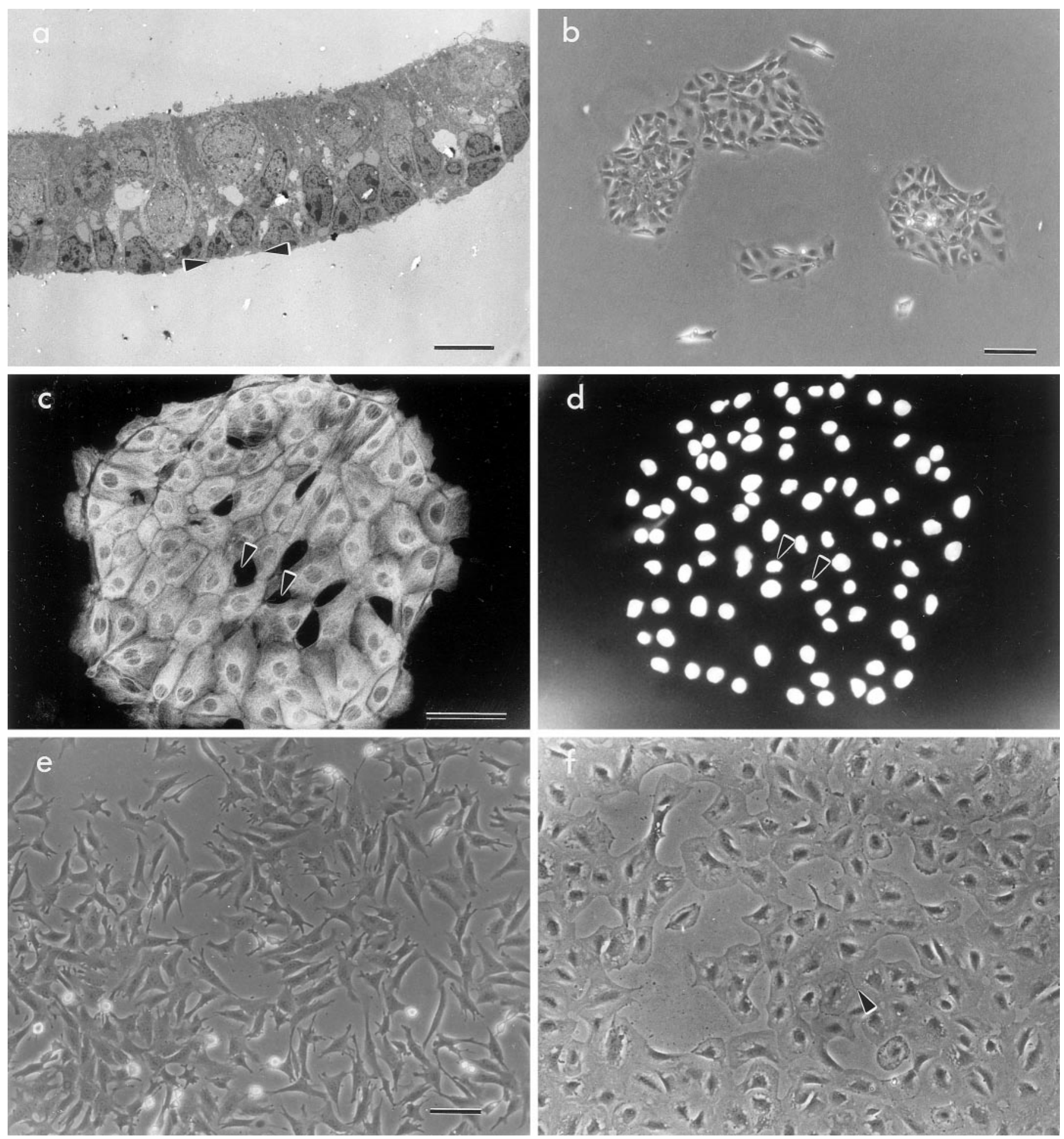

Figure 1. The origin of the utricular cell line. a, Thin section of a dissected utricular epithelium treated with thermolysin. The arrowheads indicate the base of the epithelium. Immediately above this level are the supporting cells with their relatively dark nuclei. The lighter stained nuclei belong to hair cells. The epithelium has been separated from the underlying connective tissue so that hair cells and supporting cells are the only cells present. Scale bar, $10 \mu \mathrm{m}$. $b$, Dissociated clumps of epithelium such as that shown in $a$ cultured under conditions for expression of the immortalizing gene. Scale bar, $100 \mu \mathrm{m}$. $c$, A recently isolated clump of utricular epithelium labeled by immunofluorescence for cytokeratin. The arrowheads indicate spaces occupied by hair cells. Scale bar, $50 \mu \mathrm{m}$. $d$, The same image as shown in $c$ but labeled with DAPI to show the cell nuclei. The arrowheads indicate hair cell nuclei corresponding to the arrowheads in $c$. Scale bar, $100 \mu \mathrm{m}$. $e$, The cell line UB/UE- 1 after 6 months at $33^{\circ} \mathrm{C}$ with $\gamma$-interferon. The cells proliferated rapidly under these conditions. Scale bar, $50 \mu \mathrm{m} . f$, UB/UE- 1 at $39^{\circ} \mathrm{C}$ without $\gamma$-interferon. The cells ceased dividing and assumed more symmetrical, flattened shapes like epithelial cells. The arrowhead indicates the junctions between neighboring cells. Scale bar, $50 \mu \mathrm{m}$. 


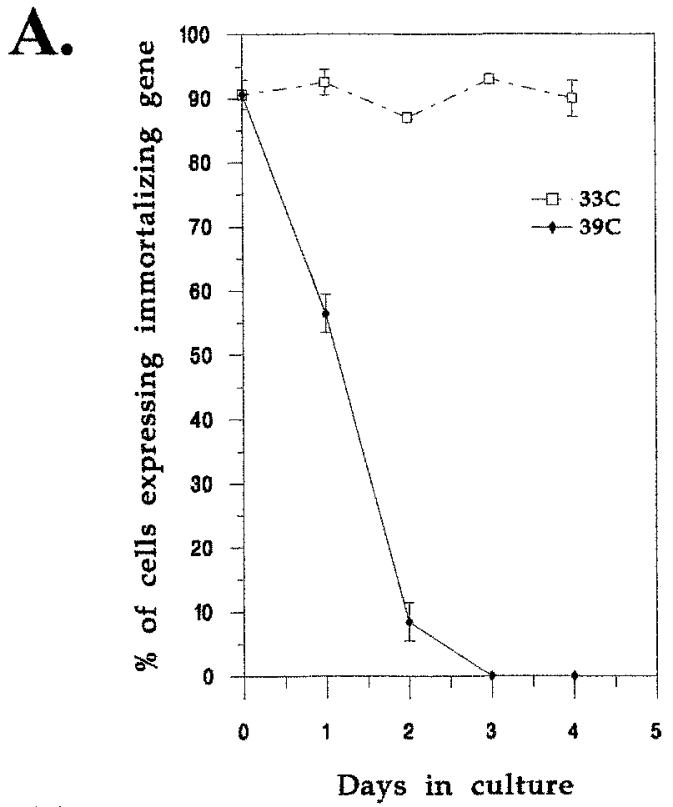

B.

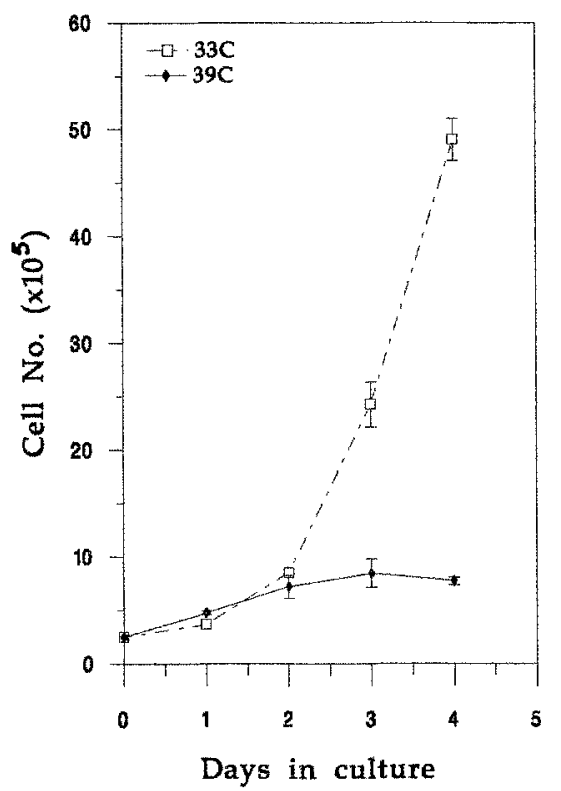

Figure 2. The relationship between cell proliferation and expression of the $\mathrm{T}$ antigen. $A$, Graph showing the percentage of the total number of cell nuclei ( $n=200$ at each point) labeled with an antibody to the $\mathrm{T}$ antigen after subculture from $33^{\circ} \mathrm{C}$ with $\gamma \mathrm{IFN}$ to $39^{\circ} \mathrm{C}$ without $\gamma \mathrm{IFN}$. The result suggests that the immortalizing gene was downregulated within 2-3 d. $b$, Graph showing the number of cells counted in cultures placed under the same conditions as those in $a$. The proliferation rate was much higher at $33^{\circ} \mathrm{C}$ with $\gamma \mathrm{IFN}$.

the sensory epithelium were trimmed away, the sheets were incubated in Minimal Essential Medium with Earle's salts and Glutamax I (MEM; Life Technologies, Paisley, Scotland) containing $500 \mu \mathrm{g} / \mathrm{ml}$ thermolysin (Protease type X, Sigma, Poole, England) (Saffer et al., 1996) for $5 \mathrm{~min}$ at $37^{\circ} \mathrm{C}$. They were then peeled from the underlying connective tissue and transferred to fresh MEM with $10 \%$ horse serum (MEM/HS; Life Technologies) and $20 \mathrm{U} / \mathrm{ml}$ dispase (Life Technologies). After $15 \mathrm{~min}$ at $37^{\circ} \mathrm{C}$, they were rinsed with fresh medium, dissociated by trituration, and plated in 35-mm-diameter dishes (Falcon range, Becton Dickinson, Oxford, England) precoated with fibronectin $\left(1 \mu \mathrm{g} / \mathrm{cm}^{2}\right.$; Life Technologies) in a small volume of MEM/HS and $100 \mathrm{U} / \mathrm{ml} \gamma$-interferon (MEM/HS/ $\gamma$ IFN) at $33^{\circ} \mathrm{C}$.

At confluence, cells were dissociated using trypsin $(0.25 \%$, Sigma) and replated in MEM/HS/ $\gamma$ IFN onto fibronectin-coated wells. They were passaged an additional two times using trypsin until confluent in $25 \mathrm{~cm}^{2}$ flasks. When cells were seeded onto uncoated tissue culture plastic in horse serum, they did not adhere well to the culture surface, so from passage 3 onward they were cultured in $10 \%$ fetal calf serum (FCS, Life Technologies). Passage 3 cells were cloned by seeding trypsin-dissociated cells at 1 cell per well in $96-w e l l$ plates in MEM/FCS/ $\gamma$ IFN. Clones were selected only from wells containing one colony. When individual clones reached confluence they were passaged using trypsin into larger vessels. Established clones were then cultured at $33^{\circ} \mathrm{C}$ in MEM $+10 \% \mathrm{FCS}$, and the $\gamma \mathrm{IFN}$ was reduced to $50 \mathrm{U} / \mathrm{ml}$. Cells were fed every 4-5 d with fresh medium and passaged approximately once per week.

To culture cells under differentiating conditions, trypsinized cells were replated in MEM/FCS without $\gamma \mathrm{IFN}$ at $39^{\circ} \mathrm{C}$. Cultures were fed every $7 \mathrm{~d}$ with fresh medium.

To measure cell proliferation, cells were seeded at $1.5 \times 10^{5}$ cells per dish in $35-\mathrm{mm}$-diameter tissue culture plastic dishes at $39^{\circ}$ and $33^{\circ} \mathrm{C}$. At set times, they were trypsinized off the dish and counted using a hemocytometer.

$P C R$. Total RNA was extracted from cells at $33^{\circ}$ and $39^{\circ} \mathrm{C}$. Primers used for the detection of the different transcripts corresponded to mouse sequences, with the exception of $\alpha 9$, which was from rat. Primers were as follows: GAPDH, positions 248 (5'-AACGGGAAGCCCATCACC-3') and 672 (5'-CAGCCTTGGCAGCACCAG-3'); $\alpha$, positions 754 (5'-CCTTACCCAGATGTCACCTTCACTC-3') and 1466 (5'-AACACCATAGCAAAGAAAATCCACA-3'); Brn3.1, positions 205 (5'-CCATGCGCCGAGTTTGTCTCC-3') and 639 (5'-CTCCACATCGCTGAGACACGC $3^{\prime}$ ); myosin VI, position 2343 (5'ACTTCCAAGATTGGATCCGAGGT-3') and 3576 (5'-GTCGTTTCATGTCAATCTCCTGC-3'); and myosin VIIa, positions 468 (5'-GCTGTATTATCAGCGGGGAG-3') and 856 (5'CTGGTGATGCAGTTACCCATG-3'). PCRs were performed under conditions that maintained the amplifications within the comparable, exponential phase determined by previous kinetic analysis. The identities of the PCR products were confirmed by sequencing and restriction enzyme digestion.

Immunocytochemical labeling of cells. Cells were characterized with numerous antibodies at $33^{\circ}$ and $39^{\circ} \mathrm{C}$ at approximately the same cell density. Cells were cultured at $33^{\circ} \mathrm{C}$ for $2-3 \mathrm{~d}$ and at $39^{\circ} \mathrm{C}$ for 2 weeks. Cultures were fixed either for $15 \mathrm{~min}$ in $4 \%$ paraformaldehyde in PBS or for $10 \mathrm{~min}$ in cold 50:50 acetone/methanol (v/v) on ice. Acetone/ methanol-fixed cultures were air-dried after fixation. Cultures fixed with $4 \%$ paraformaldehyde were labeled with antibodies to glial fibrillary acid protein (GFAP, Sigma, G-A-5), OCP-2 (gift of R. Thalmann, Washington University, St. Louis, MO), calretinin (AB149, Chemicon, Harrow, UK), parvalbumin (PA235, Sigma), $\beta$-tubulin [E7, Developmental Studies Hybridoma Bank (DSHB), University of Iowa], pan-fimbrin (737.4, gift of P. Matsudaira, Whitehead Institute for Biomedical Research, Cambridge, MA), Brn3.1 (PRB249C Babco, Berkeley, CA), and ZO-1 (R26.4c, DSHB, University of Iowa). Those fixed with a 1:1 mixture of acetone/methanol on ice were labeled with antibodies to occludin (711500 Zymed, San Francisco), pan-cytokeratin (C2562, Sigma,), vimentin (Vim13.2, Sigma), neurofilaments (200 kDa, Sigma, N4142; $165 \mathrm{kDa}$, 2H3, DSHB; 68 kDa, E1.9, DSHB), T antigen (Ab419; gift of Dr. P. Jat, Ludwig Institute for Cancer Research, London), and a range of our own monoclonal antibodies to hair cells (UB/CP1, UB/SC1, UB/SP1-3) (Nishida et al., 1998). After overnight incubation at $4^{\circ} \mathrm{C}$, antibody binding was visualized using FITC-conjugated goat anti-rabbit Ig (Sigma), FITC-conjugated goat anti-mouse IgM (Sigma), and lissamine rhodamine-conjugated goat anti-mouse IgG (Jackson Immunoresearch Labs, West Grove, PA). For control labeling of cultures, preimmune sera (where available), normal sera, or purified immunoglobulins of the appropriate species were used at comparable concentrations to the primary antibodies. Nuclei were visualized by incubating with 4',6-diamido-2phenylindole dihydrochloride (DAPI) $(1 \mu \mathrm{g} / \mathrm{ml}$ in PBS) for $5 \mathrm{~min}$ at room temperature before mounting in Vectashield (Vector Laboratories, Burlingame, CA). Labeled sections and cultures were viewed on a Nikon Optiphot II and photographed using Kodak TMY400 or Agfa RSX200.

All antibodies were also localized on $8 \mu \mathrm{m}$ cryostat sections from various prenatal and postnatal mouse inner ears. After dissection, inner ears were either snap-frozen in Tissue Tek (Agar Scientific, Cambridge, UK), sectioned, and post-fixed in acetone or fixed overnight in $4 \%$ paraformaldehyde and transferred to $30 \%$ sucrose in PBS for $2 \mathrm{hr}$ before embedding and sectioning.

For labeling of polymerized actin, cells were fixed with $4 \%$ paraformaldehyde, permeabilized with $0.5 \%$ Triton X-100 for 5 min, and labeled 

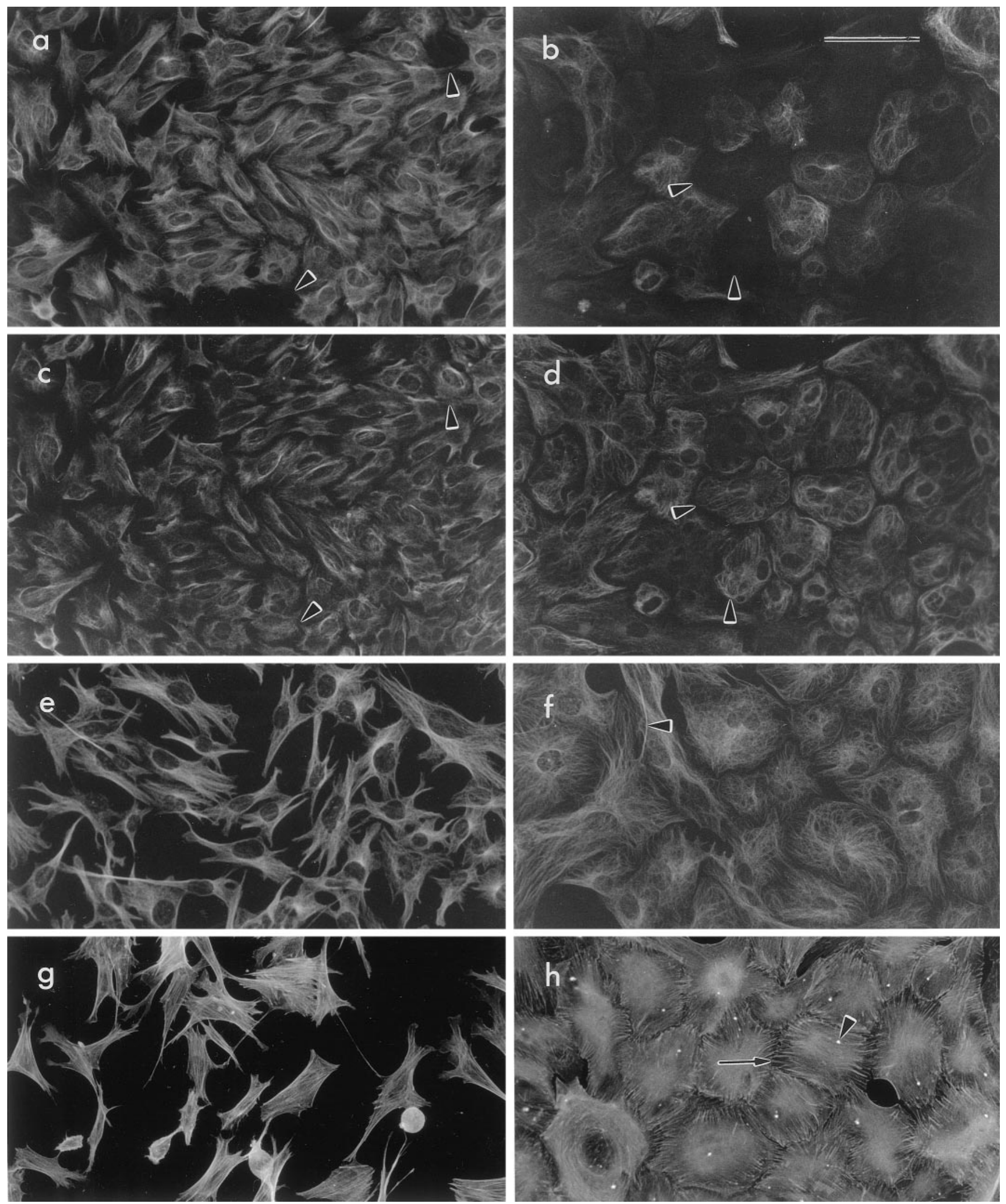

Figure 3. Expression of cytoskeletal proteins in cells under proliferating and differentiating conditions. Cells were cultured at $33^{\circ} \mathrm{C}$ with $\gamma \mathrm{IFN}(a, c$, $e, g)$ or for $14 \mathrm{~d}$ at $39^{\circ} \mathrm{C}$ without $\gamma \operatorname{IFN}(b, d, f, h)$. They were then labeled with antibodies to cytokeratin $(a, b)$, vimentin $(c, d)$, or tubulin $(e, f)$, or with rhodamine-phalloidin to label actin $(g, h)$. Most cells expressed vimentin, so the antibody to this protein was used to identify cells that did not express cytokeratin. Thus $a$ and $c\left(33^{\circ} \mathrm{C}\right)$ and $b$ and $d\left(39^{\circ} \mathrm{C}\right)$ show the same cells double-labeled for cytokeratin and vimentin. Up to $10 \%$ of cells were unlabeled for cytokeratin at $33^{\circ} \mathrm{C}$ (arrowheads in $a$ and $c$ ), but up to $60 \%$ were unlabeled at $39^{\circ} \mathrm{C}$ (arrowheads in $b$ and $d$ ). (Figure legend continues) 

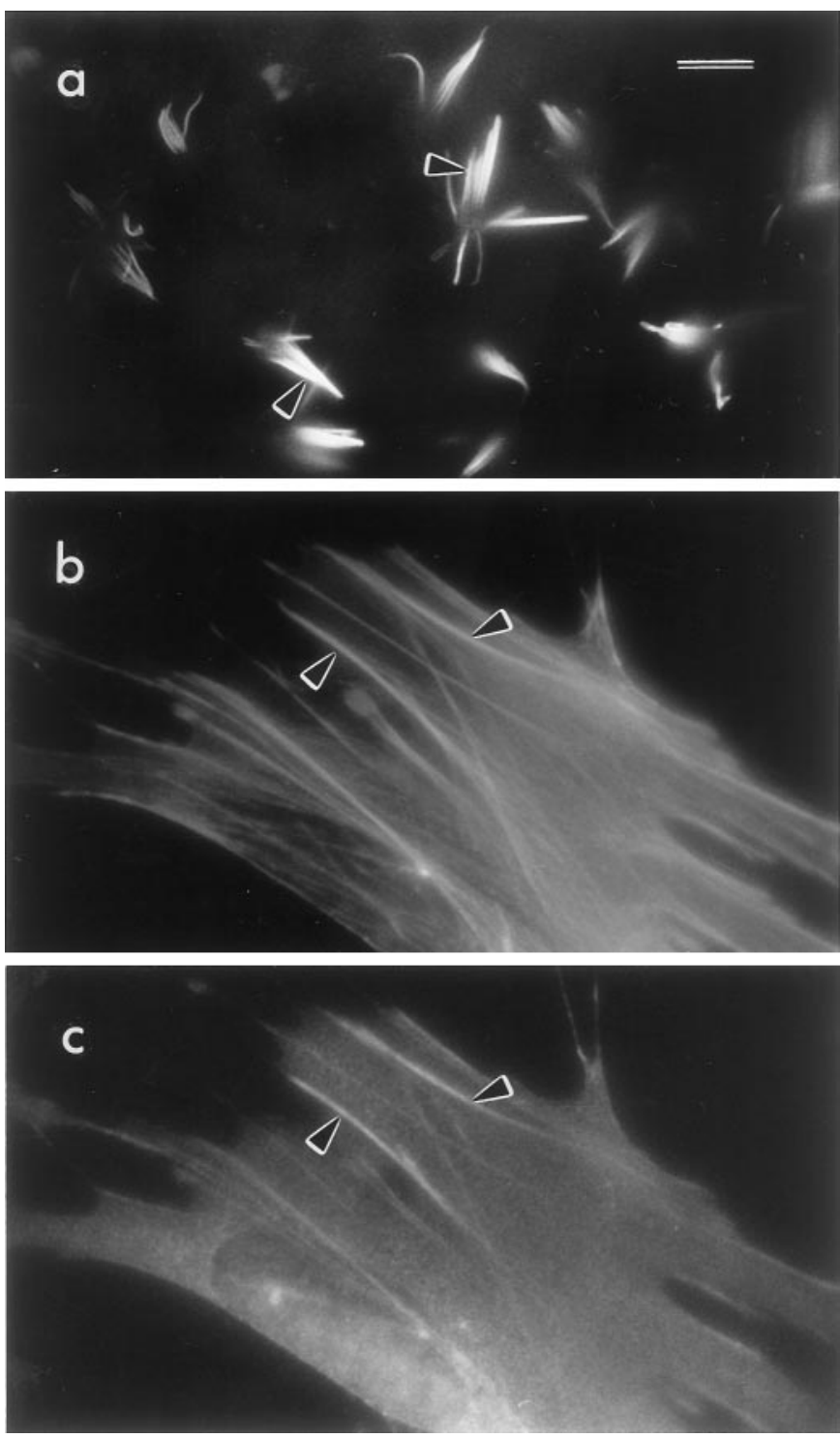

Figure 4. Fimbrin was expressed in stereocilia and in some actin bundles of cultured cells. $a$, An antibody to fimbrin specifically labeled hair bundles on utricular hair cells in organotypic cultures. $b$, A cell from $\mathrm{UB} / \mathrm{UE}-1$ at $39^{\circ} \mathrm{C}$ labeled for actin with rhodamine-phalloidin. Labeling was observed on intracellular structures resembling stress fibers (arrowheads). $c$, The same cell as shown in $b$ labeled for fimbrin. Note that all the fibers labeled for fimbrin also contained actin (arrowheads). Scale bar, $100 \mu \mathrm{m}$

'with phalloidin conjugated to tetraethyl rhodamine isothiocyanate (Sigma) or Texas Red (Molecular Probes, Eugene, OR).

Estimates of numbers of cells labeled, particularly with antibodies to cytokeratin and vimentin, were made from cells cultured in $35 \mathrm{~mm}$ Petri dishes. In each dish four sites were selected randomly, and 50 cells were counted within grid squares defined with an eye-piece graticule.

Immunoblotting. Whole-cell extracts were prepared from cells at $33^{\circ} \mathrm{C}$ after $2-3 \mathrm{~d}$ in culture and at $39^{\circ} \mathrm{C}$ after $14 \mathrm{~d}$ in culture. Cells $\left(1.5 \times 10^{6}\right)$ were extracted on ice in $750 \mu \mathrm{l}$ of buffer $(150 \mathrm{~mm} \mathrm{NaCl}, 1 \% \mathrm{NP} 40,0.1 \%$
SDS, $50 \mathrm{~mm}$ Tris, $\mathrm{pH}$ 7.4). The extract was centrifuged at $10,000 \times g$ for $10 \mathrm{~min}$ at $4^{\circ} \mathrm{C}$. After discarding the pellet the supernatant was assayed for protein concentration using a BCA assay (Pierce, Chester, England). The sample was then diluted with $2 \times$ sample buffer (10\% 2-mercaptoethanol, $4 \%$ SDS, $20 \%$ glycerol, $0.125 \mathrm{~m}$ Tris, $\mathrm{pH} 6.8$ ) and boiled for 2-3 min before aliquoting at $-80^{\circ} \mathrm{C}$.

Samples were separated on either $4-15$ or $10 \%$ SDS-PAGE gels $(5 \mu \mathrm{g}$ of protein per lane) under reducing conditions (Laemmli, 1970). After SDS-PAGE, proteins were transferred to nitrocellulose membranes (Sartorius, Göttingen, Germany), using a semi-dry blotting system, in $25 \mathrm{~mm}$ Tris, $192 \mathrm{~mm}$ glycine, 20\% methanol, and $0.1 \%$ SDS for $2 \mathrm{hr}$ at $40 \mathrm{~mA}$. Nonspecific binding sites were blocked in PBS containing $2.5 \%$ BSA and $2.5 \%$ nonfat dried milk. Blots were probed for $2 \mathrm{hr}$ with antisera against fimbrin (1:2000 dilution), Brn3.1 (1:400), and myosin VIIa (1:1000; kindly supplied by Dr. Aziz El-Amraoui, Institut Pasteur, Paris, France) followed by detection with HRP-conjugated mouse anti-rabbit monoclonal antibody (RG-96 1:5000, Sigma) and Supersignal chemiluminescence substrate (Pierce, Rockford, IL).

Electron microscopy. Cells were cultured in 35-mm-diameter Petri dishes. The culture medium was removed and replaced with $2 \%$ glutar-

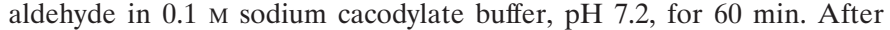
three 10 min washes in fresh buffer, the cells were post-fixed with $1 \%$ osmium tetroxide in buffer $(60 \mathrm{~min})$, washed with fresh buffer (three 10 min washes) and then distilled water $(10 \mathrm{~min})$, dehydrated with an ethanol series, and embedded in Epon that was polymerized at $60^{\circ} \mathrm{C}$ for $48 \mathrm{hr}$. Thin sections were cut on a Reichert OMU2 ultramicrotome, mounted on pioloform films on slotted grids, and stained with uranyl acetate and lead citrate.

Electrophysiology. Whole-cell patch clamp was used to record membrane currents of single UB/UE-1 cells at room temperature $\left(20-25^{\circ} \mathrm{C}\right)$. The extracellular solution contained (in $\mathrm{mM}$ ): $135 \mathrm{NaCl}, 5.8 \mathrm{KCl}, 1.3$ $\mathrm{CaCl}_{2}, 0.9 \mathrm{MgCl}_{2}, 0.7 \mathrm{NaH}_{2} \mathrm{PO}_{4}, 5.6$ D-glucose, $10 \mathrm{HEPES}-\mathrm{NaOH}$. Amino acids and vitamins for Eagle's MEM were added from concentrates (Life Technologies). The $\mathrm{pH}$ was adjusted to 7.5, and the osmolality was $\sim 302 \mathrm{mOsm} / \mathrm{kg}$. In some experiments a nominally $\mathrm{Ca}^{2+}$-free solution was used in which $\mathrm{MgCl}_{2}$ was increased to $4.8 \mathrm{~mm}$ to keep membrane charge screening approximately constant. Measured free $\mathrm{Ca}^{2+}$ was $18 \mu \mathrm{M}$. In this solution and in a solution containing $10 \mathrm{~mm}$ 4-aminopyridine (4-AP), $\mathrm{NaCl}$ was reduced to keep osmolality constant. In some experiments $100 \mu \mathrm{M}$ acetylcholine was simply added. Patch pipettes were pulled from soda glass capillaries (Clark Electromedical Instruments). To reduce the electrode capacitance, the shank of the electrode was coated with wax. The pipette filling solution contained (in mM): $145 \mathrm{KCl}, 3 \mathrm{MgCl}_{2}$, 1 EGTA-KOH, $5 \mathrm{Na}_{2}$ ATP, 5 HEPES-KOH, $\mathrm{pH}$ $7.3(288 \mathrm{mOsm} / \mathrm{kg})$. The recording electrode had a resistance in the bath of 2-3 M $\Omega$. An EPC-8 (Heka) patch-clamp amplifier was used for recordings. Data acquisition was performed using pClamp software (Axon Instruments, Foster City, CA) connected to a LabMaster DMA Interface. Data were filtered at 2.5 or $5 \mathrm{kHz}$, sampled at 5 or $20 \mathrm{kHz}$, and stored on computer for off-line analysis. Residual series resistance after compensation (40-50\%) was 2-6 M $\Omega$. Recordings and reported currents and conductances were corrected off-line for linear leakage and residual capacitative transients. Membrane potentials were corrected for series resistance, and a liquid junction potential of $-4 \mathrm{mV}$ was measured between pipette and bath solutions. Statistical comparisons of means were made by one-way ANOVA followed by Tukey's post test; differences were deemed statistically significant if $p<0.05$. Values are shown as mean $\pm \mathrm{SD}$.

\section{RESULTS}

\section{Isolation of utricular epithelial cells}

Pure sheets of hair cells and supporting cells from the utriculi of 2-d-old Immortomouse pups were obtained after treatment with thermolysin. The epithelium was dissociated from the underlying

$\leftarrow$

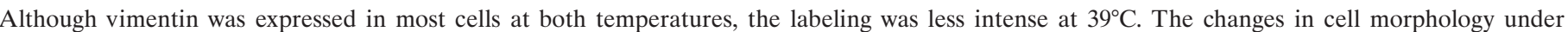

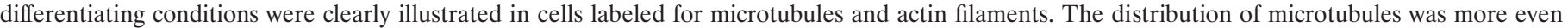

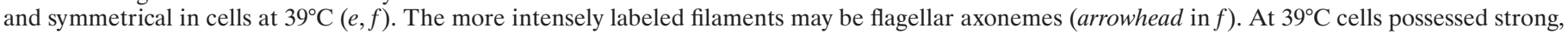

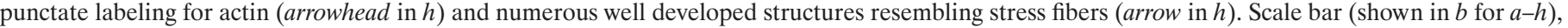
$100 \mu \mathrm{m}$. 
a)
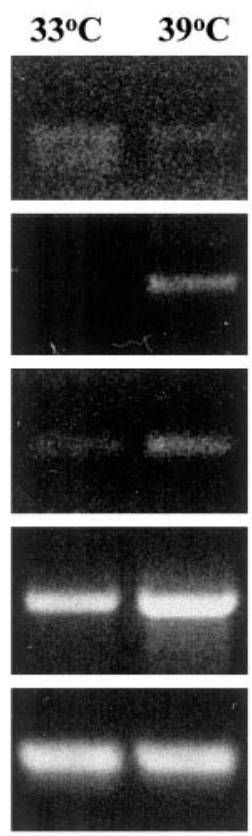

b)

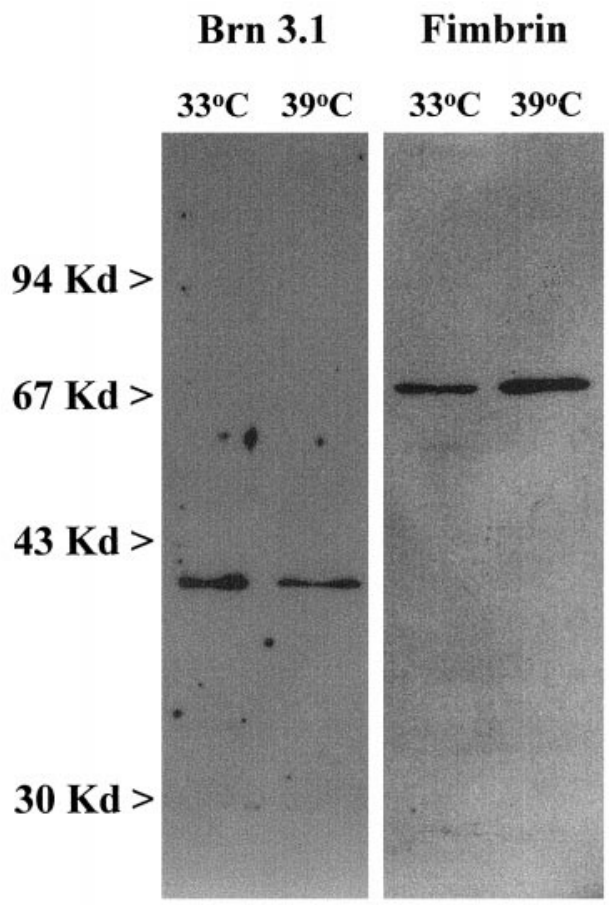

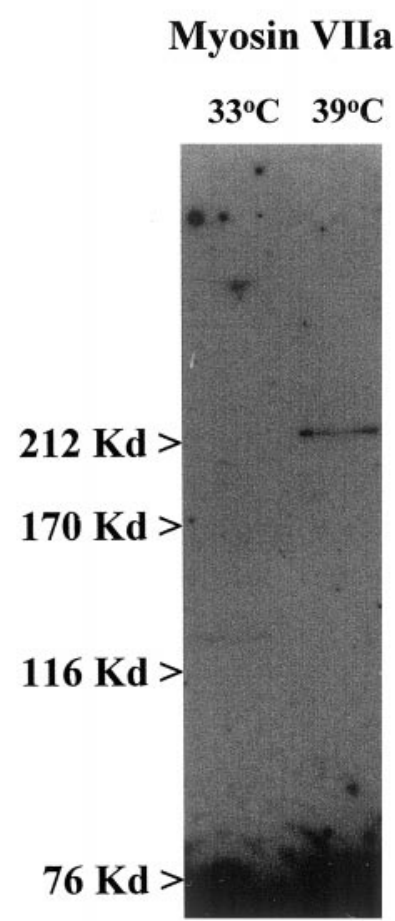

Figure 5. Expression of hair cell markers under proliferating and differentiating conditions. $a$, RT-PCR showing the relative levels of expression of different hair cell markers between cells at $33^{\circ} \mathrm{C}$ and cells at $39^{\circ} \mathrm{C}$. GAPDH was used as a normalizing control. $b$, Immunoblots of UB/UE- 1 using anti-Brn3.1, fimbrin, and myosin VIIa antibodies. The protein samples probed for Brn3.1 and fimbrin were fractionated through a 10\% SDS-PAGE, whereas the ones for myosin VIIa were run in a $6 \%$ SDS-PAGE. Each lane was loaded with $5 \mu \mathrm{g}$ of protein. A slight decrease in both mRNA and protein was observed for Brn3.1 at $39^{\circ} \mathrm{C}$. Myosin VIIa and fimbrin were upregulated at $39^{\circ} \mathrm{C}$. In general terms, the results for the immunoblots and RT-PCR correlated well except for myosin VIIa, where mRNA but not protein was detectable at $33^{\circ} \mathrm{C}$.

Table 1. Physiological properties of different cell populations

\begin{tabular}{|c|c|c|c|c|c|}
\hline & \multicolumn{4}{|c|}{$39^{\circ} \mathrm{C}$} & \multirow{2}{*}{$\begin{array}{l}\frac{33^{\circ} \mathrm{C}}{\text { Proliferating }} \\
\text { cells }\end{array}$} \\
\hline & $\begin{array}{l}\text { Sensory-type cells } \\
\text { without } I_{K 1}\end{array}$ & $\begin{array}{l}\text { Sensory-type cells } \\
\text { with } I_{K 1}\end{array}$ & $\begin{array}{l}\text { Sensory-type cells } \\
\text { (combined) }\end{array}$ & $\begin{array}{l}\text { Supporting-type } \\
\text { cells }\end{array}$ & \\
\hline Membrane input capacitance $(\mathrm{pF})$ & $70 \pm 37(15)$ & $74 \pm 43(10)$ & $72 \pm 39(25)$ & $39 \pm 29(18)$ & $48 \pm 34(40)$ \\
\hline Resting potential (mV) & $-25 \pm 5(15)$ & $-30 \pm 6(10)$ & $-27 \pm 6(25)$ & $-16 \pm 5(16)$ & $-18 \pm 5(33)$ \\
\hline Current at $+40 \mathrm{mV}(\mathrm{pA})$ & $642 \pm 208(10)$ & $697 \pm 315(9)$ & $668 \pm 258(19)$ & $97 \pm 52(13)$ & $142 \pm 120(34)$ \\
\hline Current at $-140 \mathrm{mV}(\mathrm{pA})$ & $-26 \pm 24(9)$ & $-630 \pm 286(8)$ & & $-46 \pm 26(11)$ & $-44 \pm 42(19)$ \\
\hline$g$ at $0 \mathrm{mV}(\mathrm{nS})$ & $7.4 \pm 3.4(10)$ & $10 \pm 6.8(9)$ & $8.6 \pm 5.3(19)$ & $1.4 \pm 0.9(13)$ & $2.1 \pm 2.1(34)$ \\
\hline$g_{\text {Leak }}(\mathrm{nS})$ & $1.1 \pm 0.6(10)$ & $1.3 \pm 0.5(9)$ & $1.2 \pm 0.6(19)$ & $2.3 \pm 2.8(13)$ & $4.1 \pm 3.1(34)$ \\
\hline
\end{tabular}

Values are means $\pm \mathrm{SD}$; number of cells is in parentheses.

connective tissue along the plane of the basal lamina. In similar tissue fixed for electron microscopy, only epithelial cells were observed (Fig. 1a). In the light microscope the sensory epithelium was clearly visible, and trimming the edges ensured that all nonsensory epithelial cells were removed. This was confirmed by labeling dissected epithelia with rhodamine-phalloidin to show the presence of hair cells. In early experiments, the isolated maculae were plated as intact epithelial sheets, but outgrowth was limited to the edge of the explant, raising the possibility that we were selecting a subpopulation of supporting cells from the edge. By dissociating the epithelial sheet, it was possible to obtain cell clumps from throughout the whole epithelium (Fig. 1b). Cell outgrowth was evident from most epithelial clumps, confirming that viable, dividing cells were present throughout the dissected epithelium. In these clumps, all cells expressed cytokeratins except for the remaining hair cells (Fig. 1c,d). These results showed that the primary cultures were composed exclusively of utricular sensory epithelial cells.

Epithelial cell proliferation was dependent on the expression of $\mathrm{T}$ antigen, because wild-type cultures maintained in the same medium showed little or no outgrowth compared with the immortalized cells. At confluence, primary cultures were passaged into fresh dishes. The cells expressed cytokeratin and vimentin but not GFAP or neurofilaments at $33^{\circ} \mathrm{C}$. After a number of additional passages, some lost their cytokeratin expression. Stable cytokeratin-positive cell lines were established from these cultures by limiting dilution cloning, and one of these lines, UB/ UE-1 (Fig. 1e,f), was used for these studies. Expression of cyto- 


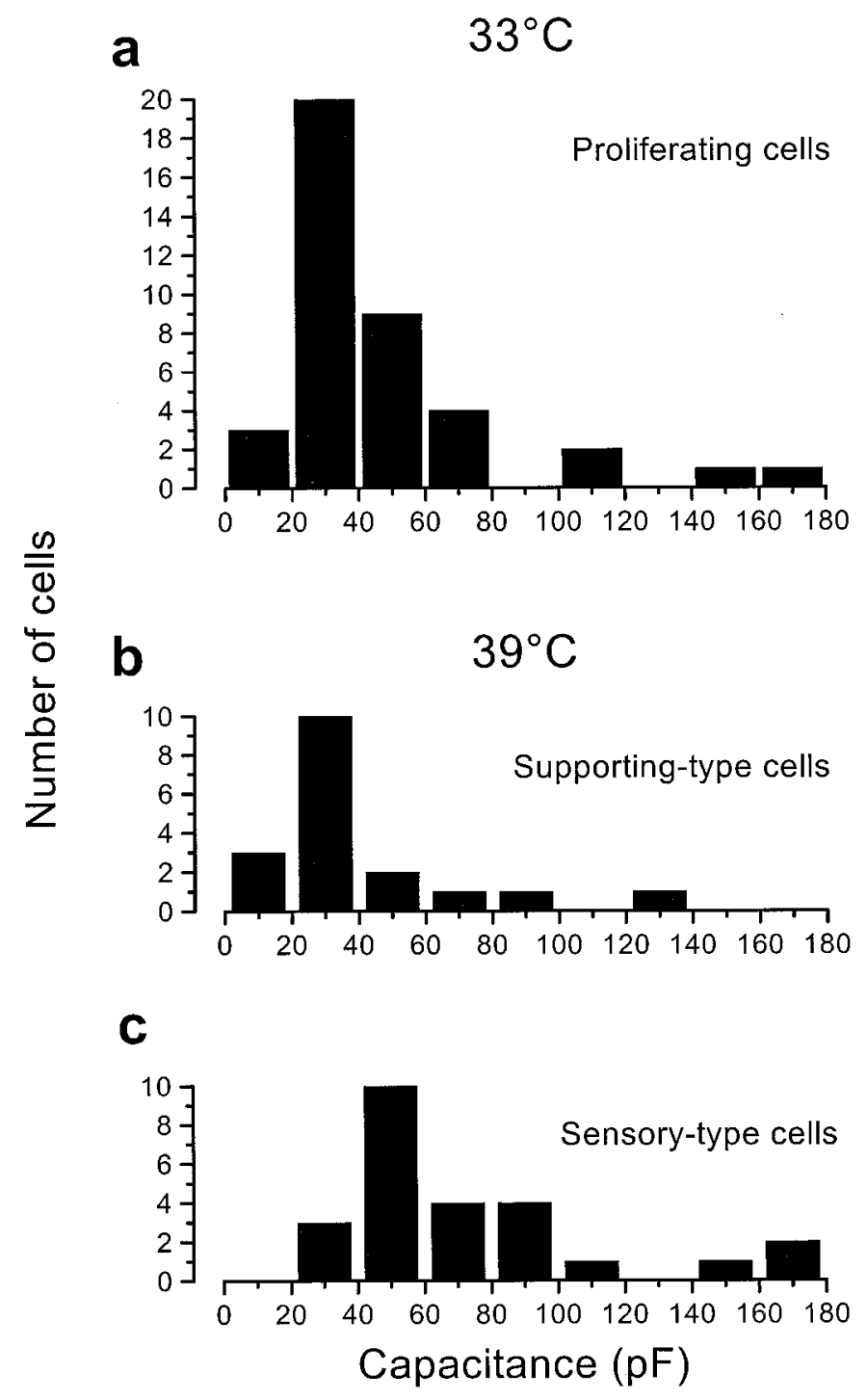

Figure 6. Histograms showing the distribution of membrane capacitance $\left(C_{\mathrm{m}}\right)$ in the different groups of cells. $a$, Cells grown at $33^{\circ} \mathrm{C}(n=40) ; b$, supporting-type cells grown at $39^{\circ} \mathrm{C}(n=18) ; c$, Sensory-type cells grown at $39^{\circ} \mathrm{C}(n=25)$. Bin width is $20 \mathrm{pF}$.

keratin was used as confirmation that selected clones were derived from supporting cells and not from existing hair cells.

At $33^{\circ} \mathrm{C}$ in the presence of $\gamma \mathrm{IFN}, 90 \%$ of the cells were labeled with antibody against the $\mathrm{T}$ antigen, the label being restricted to the nucleus. After plating out at $39^{\circ} \mathrm{C}$ without $\gamma \mathrm{IFN}$, the number of labeled cells dropped to $<10 \%$ in $2 \mathrm{~d}$, and by $3-4 \mathrm{~d}$ none were labeled (Fig. 2A). This reduction in $\mathrm{T}$ antigen expression was related to a decrease in cell division (Fig. $2 B$ ). Proliferation continued past confluence at $33^{\circ} \mathrm{C}$, and the cells became very tightly packed. At $39^{\circ} \mathrm{C}$, however, the cells stopped proliferating and rapidly adopted a flattened "fried-egg" morphology and formed some cell-cell contacts (Fig. 1f).

\section{Expression of supporting and hair cell markers}

Cytokeratin was expressed in $>90 \%$ of cells at $33^{\circ} \mathrm{C}$ (Fig. $3 a$ ), and this level of expression was stable over a large number of population doublings. At $39^{\circ} \mathrm{C}$ the proportion of positive cells decreased to $\sim 40 \%$, and the intensity of labeling in those cells still expressing cytokeratin (Fig. 3b) was reduced. Objective assess- ment of cytokeratin expression was not clear-cut because a few labeled strands were often observed in cells that otherwise appeared to be unlabeled. In contrast, vimentin continued to be expressed in $>95 \%$ of cells at both $33^{\circ}$ and $39^{\circ} \mathrm{C}$ (Fig. $3 c, d$ ). Labeling with pan-cadherin antibodies showed little evidence for cell-cell junctions at $33^{\circ} \mathrm{C}$ but clear evidence of adherens-type junctions at $39^{\circ} \mathrm{C}$ (data not shown).

The immunolabeling for microtubules clearly revealed the change in general cell morphology at the two temperatures (Fig. $3 e, f)$. The dense labeling at $39^{\circ} \mathrm{C}$ made it difficult to discern individual structures, but despite the appearance of more intensely labeled filaments (Fig. $3 f$ ) and the identification of flagellar axonemes by electron microscopy (see below), there did not appear to be any evidence for organized kinocilia. The label for actin showed two relevant differences in morphology (Fig. $3 g, h$ ). Cells at $39^{\circ} \mathrm{C}$ possessed many more actin filament bundles, or "stress fibers," and in most cases a very bright, punctate structure formed close to the center (Fig. 3h). Although well ordered hair bundles were not observed, some of these stress fibers labeled for fimbrin, an actin bundling protein that has previously been localized to stereocilia of mouse vestibular hair cells. Immunolabeling of primary cultures of vestibular epithelia from normal mice showed that fimbrin localized only to stereocilia within hair cells but was absent from supporting cells (Fig. 4a). In cells from $\mathrm{UB} / \mathrm{UE}-1$, fimbrin was also expressed in focal contact-like, actinlabeled structures at the free edges of cells (Fig. 4b,c). It did not appear to coincide with the punctate label observed with phalloidin.

RT-PCR and immunoblotting revealed the expression of several genes normally expressed selectively by hair cells (Fig. 5). mRNA for Brn3.1 was detected at low levels under both conditions but was apparently expressed at lower levels at $39^{\circ} \mathrm{C}$. Immunoblotting for the Brn3.1 protein confirmed this result. mRNA for the $\alpha 9 \mathrm{AChR}$ was not detected at $33^{\circ} \mathrm{C}$ but was clearly present at $39^{\circ} \mathrm{C}$, suggesting that the gene was only expressed under differentiating conditions. Lack of a suitable antibody for the $\alpha 9 \mathrm{AChR}$ meant that we were unable to verify the level of protein expression. Trace levels of mRNA for myosin VIIa were detected at $33^{\circ} \mathrm{C}$, with higher levels at $39^{\circ} \mathrm{C}$. By immunoblotting, no myosin VIIa protein was detected at $33^{\circ} \mathrm{C}$, but a band of $220 \mathrm{kDa}$ was detected at $39^{\circ} \mathrm{C}$ showing that protein expression also increased. mRNA for myosin VI was expressed under both conditions and also appeared to be more abundant at $39^{\circ} \mathrm{C}$.

The antibodies to fimbrin recognized a $68 \mathrm{kDa}$ band by immunoblotting, and this labeling suggested that expression was higher at $39^{\circ} \mathrm{C}$ than at $33^{\circ} \mathrm{C}$ (Fig. $5 b$ ). These results confirmed the specificity of the label and correlated with the higher number of stress fibers that formed at $39^{\circ} \mathrm{C}$. The cell line did not express calretinin, OCP-2, UB/CP1, UB/SC1, UB/SP1-3, ZO-1, or occludin at either temperature as judged by either immunofluorescence-labeling or immunoblotting .

\section{Ionic currents in cells grown at $33^{\circ} \mathrm{C}$}

Cells grown at $33^{\circ} \mathrm{C}$, hereafter referred to as proliferating cells, were visibly variable in size, an observation confirmed by the large SD of the membrane capacitance (Table 1; Fig. 6). All cells investigated exhibited a small negative resting membrane potential of -10 to $-30 \mathrm{mV}$. Typical examples of membrane responses, during application of depolarizing and hyperpolarizing voltage steps, are shown in Figure $7 a, b$. In all cells investigated, depolarizing steps from a holding potential of $-64 \mathrm{mV}$ elicited small, seemingly instantaneous outward currents from potentials posi- 


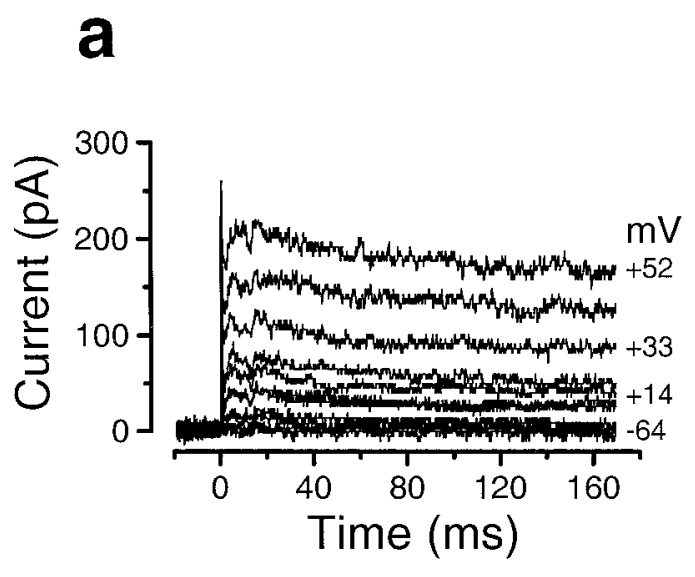

b

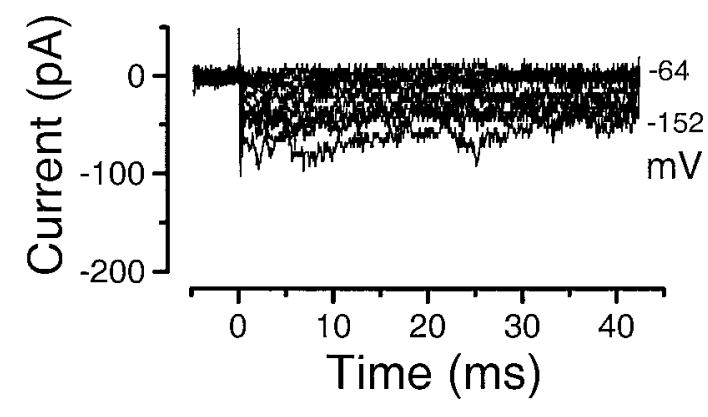

a

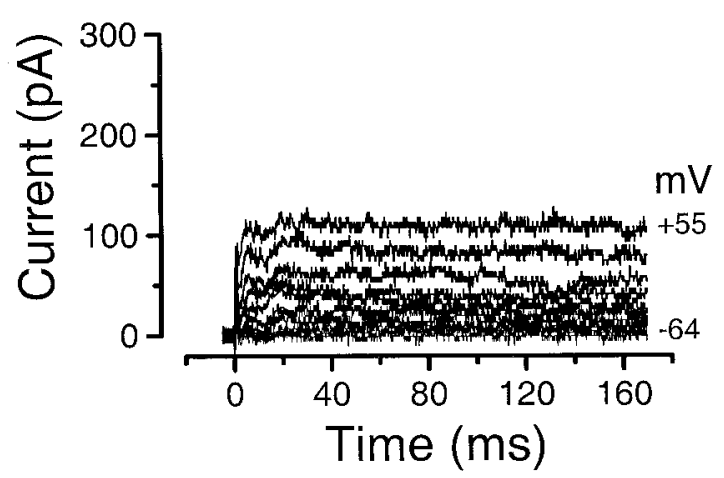

b

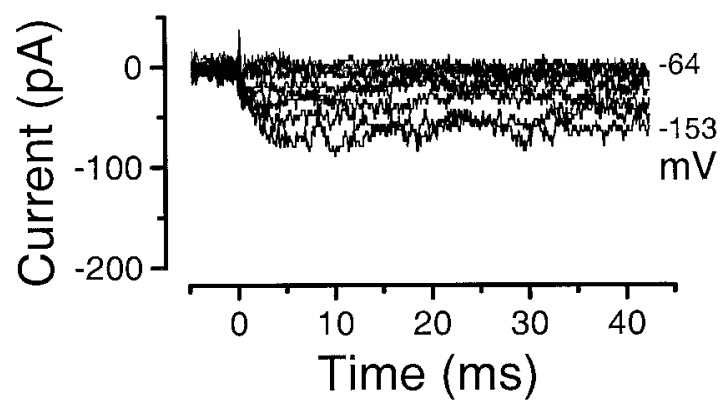

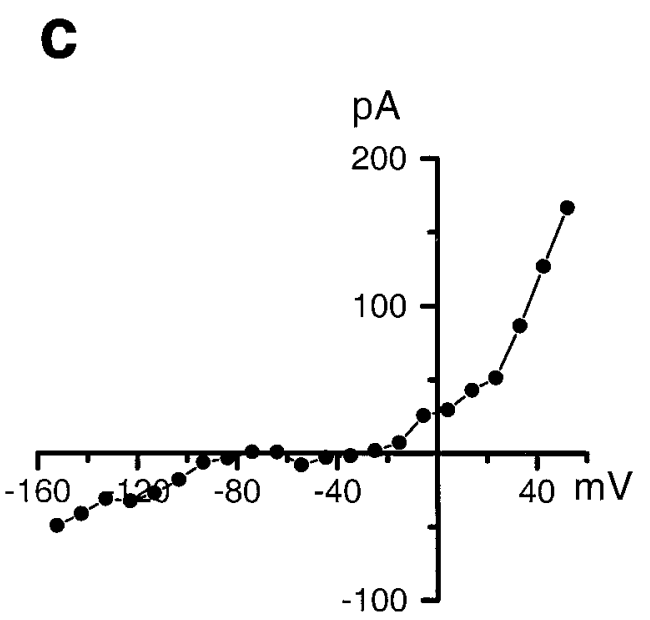

Figure 7. Membrane currents under voltage clamp in a $\mathrm{UB} / \mathrm{UE}-1$ cell grown at $33^{\circ} \mathrm{C}$. $a$, Outward currents from a holding potential of $-64 \mathrm{mV}$ elicited by depolarizing voltage steps in nominal increments of $10 \mathrm{mV}$ (actual membrane potentials shown by some of the traces). $b$, Responses to hyperpolarizing steps in nominal $10 \mathrm{mV}$ increments from $-64 \mathrm{mV}$. Note the absence of inward currents. $c$, Steadystate current-voltage $(I-V)$ curve of currents shown in $a$ and $b$. The steady-state currents in Figures 7-11 were measured near the end of the voltage steps $(t=170 \mathrm{msec}$ for depolarizing steps and $t=40 \mathrm{msec}$ for hyperpolarizing steps). All records are single traces in this and all subsequent figures. $V_{\mathrm{m}}=-12 \mathrm{mV} ; C_{\mathrm{m}}=21 \mathrm{pF}$; residual $R_{\mathrm{s}}=4.3$ $\mathrm{M} \Omega ; 22^{\circ} \mathrm{C}$. Linear leak subtracted: $3.7 \mathrm{nS}$.

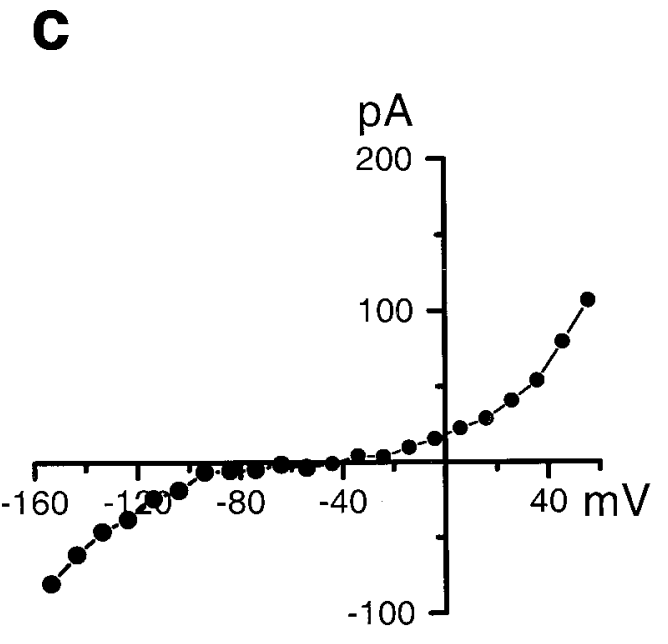

Figure 8. Membrane currents in a UB/UE-1 supportingtype cell grown at $39^{\circ} \mathrm{C}$. $a$, Outward currents from $-64 \mathrm{mV}$. $b$, Inward currents from $-64 \mathrm{mV}$. $c$, Steady-state $I-V$ curve of currents shows in $a$ and $b . V_{\mathrm{m}}=-14 \mathrm{mV} ; C_{\mathrm{m}}=13 \mathrm{pF}$; residual $R_{\mathrm{s}}=3.6 \mathrm{M} \Omega ; 23^{\circ} \mathrm{C}$. Linear leak subtracted: $1.5 \mathrm{nS}$. 

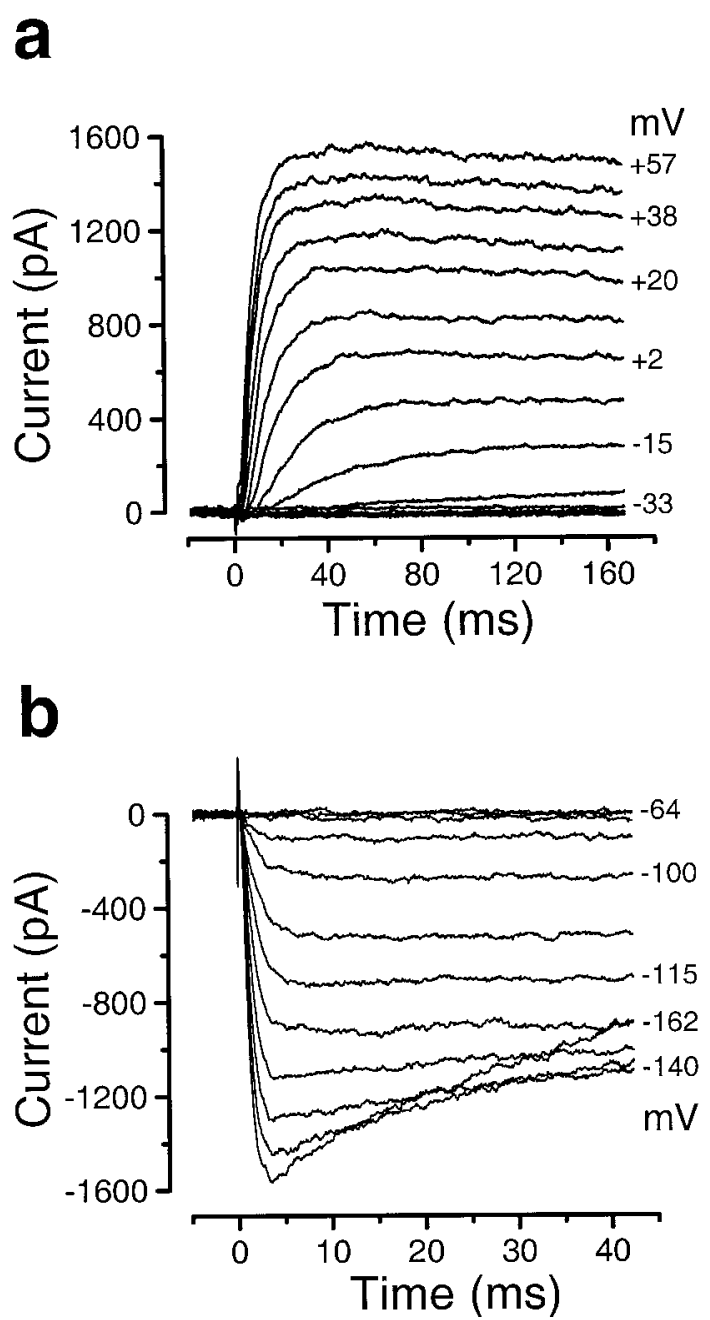

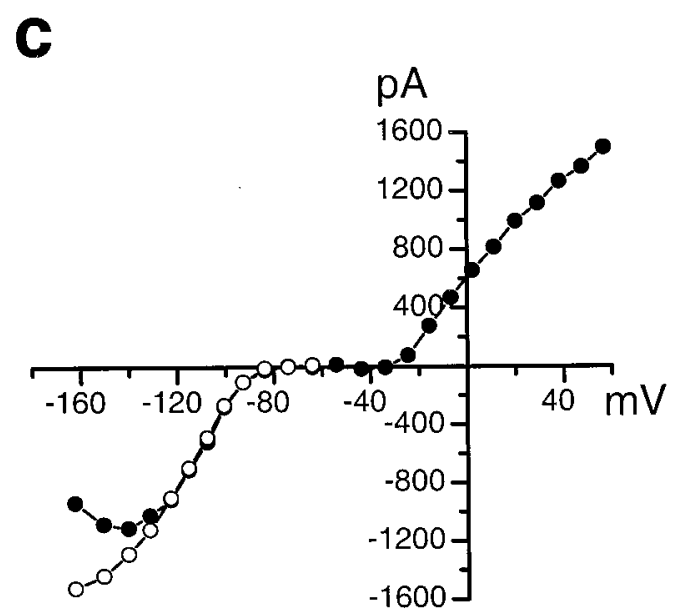

d

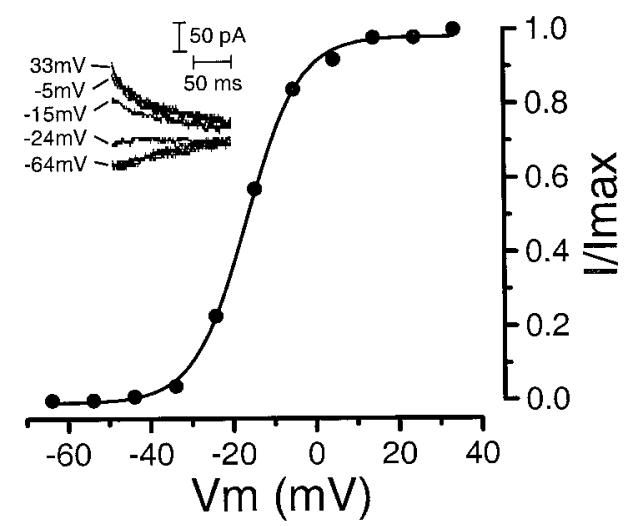

Figure 9. Membrane currents under voltage clamp in UB/UE-1 sensory-type cells with inward rectifier grown at $39^{\circ} \mathrm{C} . a$, Outward currents in response to depolarizing voltage steps from $-64 \mathrm{mV}$ to the various test potentials shown by some of the traces. $b$, Inward currents of the same cell to hyperpolarizing steps from $-64 \mathrm{mV}$. Note the decay of the currents for potentials negative to $-130 \mathrm{mV}$. $c$, Steady-state $I-V$ curves of currents shown in $a$ and $b(\bullet)$ and peak $I-V(\bigcirc)$ of currents shown in $b . V_{\mathrm{m}}=-29 \mathrm{mV} ; C_{\mathrm{m}}=48 \mathrm{pF}$; residual $R_{\mathrm{s}}=6 \mathrm{M} \Omega ; 23^{\circ} \mathrm{C}$. Linear leak subtracted: $1.0 \mathrm{nS}$. $d$, Steady-state activation curve of the outward currents in another cell. The inset shows the tail currents on returning to a test potential of $-24 \mathrm{mV}$ after $170 \mathrm{msec}$ steps to a range of potentials between $-64 \mathrm{mV}$ and $+33 \mathrm{mV}$ in nominal increments of $10 \mathrm{mV}$. The curve is the best fit to the Boltzmann equation (see Results), with $I_{\max }=209 \mathrm{pA}, V_{1 / 2}=-16.6 \mathrm{mV}$, and S $=6.7 \mathrm{mV} . V_{\mathrm{m}}=-39 \mathrm{mV} ; C_{\mathrm{m}}=52 \mathrm{pF} ;$ residual $R_{\mathrm{s}}=4 \mathrm{M} \Omega ; 23^{\circ} \mathrm{C}$. Linear leak subtracted: $0.9 \mathrm{nS}$.

tive to about $-20 \mathrm{mV}$. Only small inward currents could usually be detected during application of hyperpolarizing voltage steps from the same holding potential. A typical steady-state currentvoltage $(I-V)$ relationship is shown in Figure $7 c$. No electrical responses were observed after application of $100 \mu \mathrm{M}$ acetylcholine to cells whose membrane potential was held at $-54 \mathrm{mV}$ $(n=13)$.

\section{lonic currents in cells grown at $39^{\circ} \mathrm{C}$}

At $39^{\circ} \mathrm{C}$ the membrane currents were more heterogeneous than at $33^{\circ} \mathrm{C}$. On the basis of differences in current responses, cells were grouped in three categories: two with currents similar to those in normal vestibular hair cells, and one with currents similar to those of normal supporting cells. These categories of cells will be referred to as "sensory-type cells" and "supporting-type cells." Sensory-type cells were first encountered after 6 d at $39^{\circ} \mathrm{C}$, and all three groups were still present after $45 \mathrm{~d}$, the longest time tested. The resting membrane potentials of sensory-type cells (range -15 to $-40 \mathrm{mV} ; n=25$ ) were significantly different from those of both supporting-type cells $(-10$ to $-25 \mathrm{mV}, n=16 ; p<0.001)$ and proliferating cells $(-10$ to $-30 \mathrm{mV}, n=33 ; p<0.001)$ (Table 1). Although all cell types had a wide range of membrane capacitance, the mean capacitance of the sensory-type cells was larger than both the supporting-type $(p<0.01)$ and proliferating cells $(p<0.05)$ (Fig. 6). No significant differences in membrane potential or capacitance were found between supporting-type and proliferating cells.

\section{Ionic currents in supporting-type cells}

Figure $8 a, b$ shows a representative set of traces. In almost all cells, depolarizing steps from $-64 \mathrm{mV}$ evoked tiny, almost instantaneous outward currents. Hyperpolarizing steps from the same potential elicited small and sustained inward currents. The steady-state $I-V$ relationship (Fig. $8 c$ ) indicated small amounts of outward and inward rectification positive to -20 and negative to $-90 \mathrm{mV}$, respectively. When acetylcholine was applied, no responses were recorded from seven of eight cells held at $-54 \mathrm{mV}$. One cell produced a very small inward current. 

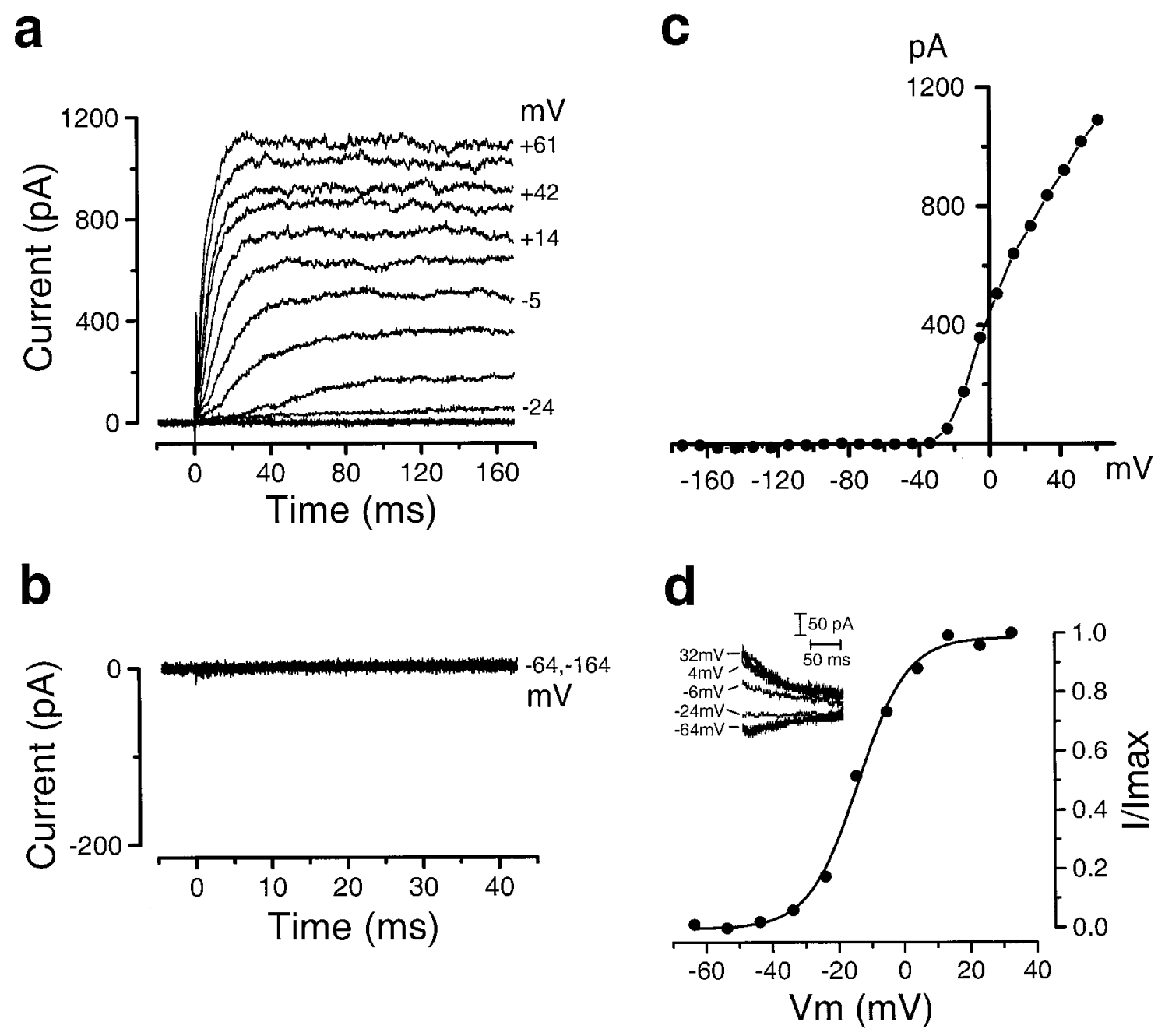

Figure 10. Membrane currents in a UB/UE-1 sensory-type cell without inward rectification, grown at $39^{\circ} \mathrm{C}$, under voltage-clamp conditions. $a$, Outward currents from $-64 \mathrm{mV} . b$, Lack of inward currents from $-64 \mathrm{mV}(12$ nominal $10 \mathrm{mV}$ steps down to $-174 \mathrm{mV})$. $c$, Steady-state $I-V$ curve of currents shown in $a$ and $b . d$, Steady-state activation curve of the outward currents. The inset shows the tail currents on returning to a test potential of $-24 \mathrm{mV}$. Boltzmann fit: $I_{\max }=227 \mathrm{pA}, V_{1 / 2}=-14.1 \mathrm{mV}$, and S $=7.5 \mathrm{mV} . V_{\mathrm{m}}=-24 \mathrm{mV} ; C_{\mathrm{m}}=41 \mathrm{pF}$; residual $R_{\mathrm{s}}=6 \mathrm{M} \Omega ; 23^{\circ} \mathrm{C}$. Linear leak subtracted: $0.6 \mathrm{nS}$.

\section{Ionic currents in sensory-type cells}

Typical examples of voltage-dependent potassium currents recorded from a holding potential of $-64 \mathrm{mV}$ for the two different groups of sensory-type cells are shown in Figures 9, 10. In these cells, depolarizing voltage steps caused slowly activating voltagedependent outward currents that were much larger than those in the other cell types. A small inward current, probably carried by calcium ions, preceded the outward current in some cells. The time of half-maximal activation of the outward currents decreased as a function of increasing test potential and in both groups was $\sim 13 \mathrm{msec}$ around $0 \mathrm{mV}$ and $6 \mathrm{msec}$ around $+40 \mathrm{mV}$. The steady-state values of the outward currents were measured near the end of the test pulse to generate $I-V$ curves. Outward current started to activate at potentials close to $-40 \mathrm{mV}$. The size of the current, measured at $+40 \mathrm{mV}$, ranged from 400 to $1300 \mathrm{pA}$. Superfusion with nominally $\mathrm{Ca}^{2+}$-free solution had no effect on this current $(n=5)$. Superfusion with $10 \mathrm{~mm}$ 4-AP reversibly reduced the outward currents (measured near $+50 \mathrm{mV}$ ) by $\sim 65 \%$ $(n=5)$.

Hyperpolarizing voltage steps elicited inward currents only in $40 \%$ of sensory-type cells. A typical example of the inward rectifier current is shown in Figure $9 b$. The current rapidly reached a plateau that was maintained throughout the voltage steps down to approximately $-130 \mathrm{mV}$. At more negative potentials, the currents decayed in a voltage-dependent manner. The $I-V$ relationship (Fig. $9 c$ ) shows that the inward current activated negative to $-80 \mathrm{mV}$ and that peak and late currents started to diverge negative to $-130 \mathrm{mV}$. In other sensory-type cells, hyperpolarizing steps did not elicit any time- or voltage-dependent current (Fig. 10b). Long (500 msec) hyperpolarizing voltage steps elicited no evidence of the slowly activating weak inward rectifier $I_{\mathrm{h}}$ (Holt and Eatock, 1995).

The activation curves of the outward currents recorded in the two groups of sensory-type cells were generated by analyzing tail currents at a fixed test membrane potential (Figs. 9d, 10d). The outward current activated at potentials close to $-40 \mathrm{mV}$ and was almost completely recruited close to $0 \mathrm{mV}$. Data were fitted by the first-order Boltzmann equation: $I=I_{\max } /\left\{1+\exp \left[\left(V_{1 / 2}-V_{\mathrm{m}}\right) /\right.\right.$ $S]$, in which $I$ is the tail current measured $1 \mathrm{msec}$ after the step to the test potential, $I_{\max }$ is the maximal tail current, $V_{1 / 2}$ is the potential at which the half-maximal activation occurred, $V_{\mathrm{m}}$ is the membrane potential of the voltage step preceding the test poten- 


\section{a}

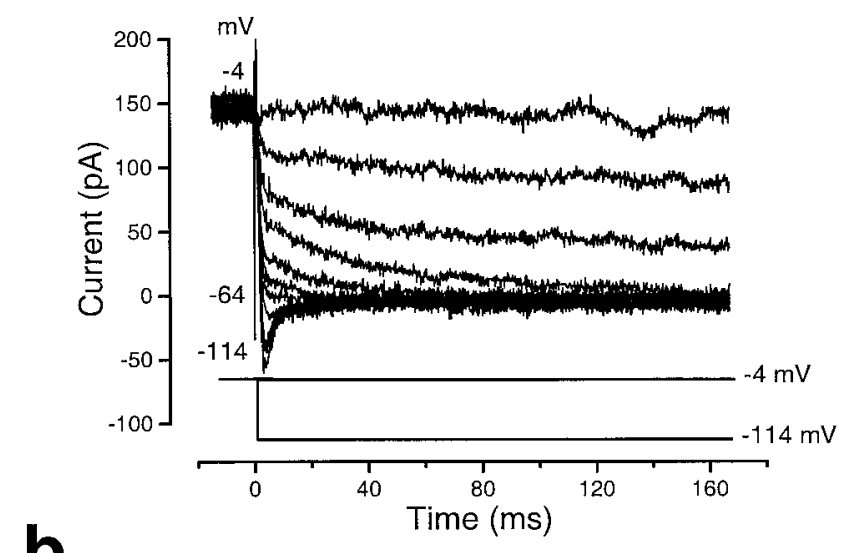

b

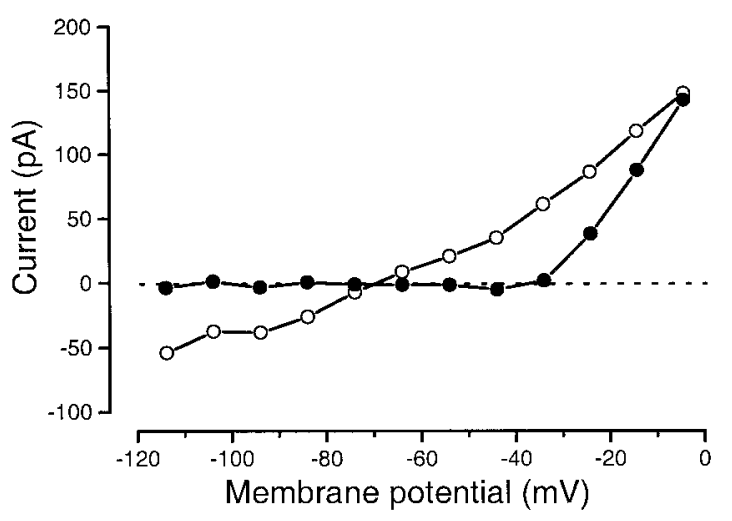

Figure 11. Reversal potential of $I_{\mathrm{K}}$ of a sensory-type cell without inward rectifier. $a$, Tail currents in response to voltage steps to potentials between -114 and $-4 \mathrm{mV}$ after a $170 \mathrm{msec}$ conditioning step to $-4 \mathrm{mV}$ (protocol shown schematically below). $b$, Tail currents $1 \mathrm{msec}$ after the voltage step $(\bigcirc)$ and at the steady state $(\bullet)$ plotted against voltage. Reversal potential $(-70 \mathrm{mV})$ taken as the intersection of the two curves. $V_{\mathrm{m}}=-29 \mathrm{mV}$; $C_{\mathrm{m}}=47 \mathrm{pF}$; residual $R_{\mathrm{s}}=2.3 \mathrm{M} \Omega ; 23^{\circ} \mathrm{C}$. Linear leak subtracted: $0.7 \mathrm{nS}$.

tial, and $S$ describes the voltage sensitivity of activation. No significant differences were found in $V_{1 / 2}$ and $S$ between the two groups of cells. $V_{1 / 2}$ and $S$ in sensory-type cells that show inward rectification were $-14.9 \pm 1.5 \mathrm{mV}(n=3)$ and $7.7 \pm 1.1 \mathrm{mV}(n=$ 3 ), respectively. $V_{1 / 2}$ and $S$ values in sensory-type cells without inward rectification were $-13.6 \pm 1.4 \mathrm{mV}(n=3)$ and $8.0 \pm 1.6$ $\mathrm{mV}(n=3)$. Application of acetylcholine elicited an inward current of up to $200 \mathrm{pA}$ in four of five sensory-type cells cultured at $39^{\circ} \mathrm{C}$ when held at a holding potential of $-54 \mathrm{mV}$, thus confirming the expression of functional receptors as suggested by the results from the RT-PCR.

\section{Ionic basis of the outward current}

The ionic basis of the outward current in sensory-type cells was established by analyzing the tail currents at different potentials after a step potential to near $0 \mathrm{mV}$ for $170 \mathrm{msec}$, from a holding potential of $-84 \mathrm{mV}$. A family of tail currents elicited in a solution containing a normal concentration of $\mathrm{K}^{+}(5.8 \mathrm{~mm})$ is shown in Figure 11a. The tail currents at the peak and at the steady state were plotted against potential to generate $I-V$ curves (Fig. 11b). The reversal potential was taken as the intersection of the two curves (Ritchie, 1987). Tail currents reversed at $-62 \pm 9$
$\mathrm{mV}(n=3)$, near the $\mathrm{K}^{+}$equilibrium potential $(-83 \mathrm{mV})$ calculated for our experimental conditions using the Nernst equation. These results indicate that the outward current was mainly carried by potassium ions.

\section{Electron microscopy}

Cultured cells were $\sim 50-60 \mu \mathrm{m}$ in diameter and 1-3 $\mu \mathrm{m}$ thick (Fig. 12a). In the central, nuclear region the thickness increased to $\sim 5 \mu \mathrm{m}$. Electron-dense, punctate structures were observed around the cell margins, but there was no evidence for continuous intercellular junctions. The most notable feature of some cells at $39^{\circ} \mathrm{C}$ was a thickened cytoskeletal meshwork underlying the entire apical surface penetrated by focal cytoskeletal structures resembling microvillar rootlets (Fig. 12b). These rootlets almost certainly represented at least a subset of the stress fibers labeled with phalloidin and viewed in the light microscope (Fig. $3 h$ ). From some cells microvillar projections emerged from the cell surface, but only a few structures like this were observed in thin section (Fig. 12c). The mesh, rootlets, and projections were all composed of microfilaments $4-6 \mathrm{~nm}$ thick. Ciliary axonemes lay across the surfaces of cells and were visible both in transverse section (Fig. 12d) and in scanning images at low power (data not shown).

\section{DISCUSSION}

We have established a clonal, conditionally immortal cell line from a postnatal, mammalian vestibular sensory epithelium. The cells differentiate into three discrete types that can be distinguished unambiguously by the ionic channels that they express in the plasma membrane. The two sensory-type cells resemble variants of normal, neonatal, vestibular hair cells, and the supportingtype resembles normal vestibular supporting cells. The identity of the cells under proliferating conditions is based on the initial preparation of pure sensory epithelia and on selection for cells that express cytokeratins. Pure epithelia are composed of hair cells and supporting cells, but although differentiated hair cells survive for some weeks in our cultures, they never express cytokeratins or mitotic figures. The electrophysiology of membrane currents provides an objective, functional assay for the identity of different cell types, and it is this evidence that forms the basis of our conclusions.

Many different types of hair cell express a characteristic, delayed rectifier potassium current $\left(I_{\mathrm{K}}\right)$ (Fuchs, 1992). The sensorytype cells from UB/UE-1 express a slow-activating, outward potassium current recruited at potentials positive to $-40 \mathrm{mV}$ with a time course characterized by a relatively slow half-maximal activation $(\sim 13 \mathrm{msec}$ at $0 \mathrm{mV})$ and by the lack of any fast inactivation during $170 \mathrm{msec}$ test pulses. These properties, together with the sensitivity to block by 4-AP and the insensitivity to extracellular calcium levels, suggest that they express a typical $I_{\mathrm{K}}$ current.

Delayed rectifiers represent the principal potassium current in type II hair cells of several vestibular organs (Lang and Correia, 1989; Griguer et al., 1993; Masetto et al., 1994; Masetto and Correia, 1997), where they contribute to shaping the receptor potential. Type I vestibular hair cells are dominated by a much larger potassium conductance, $I_{\mathrm{K}, \mathrm{L}}$, which is activated at very negative potentials (Rennie and Correia, 1994; Rüsch and Eatock, 1996). This conductance is so large that it normally masks any other outward potassium conductances in type I cells. Residual potassium conductances are revealed on blocking $I_{\mathrm{K}, \mathrm{L}}$ pharmacologically. In guinea pigs, such a conductance has been iden- 

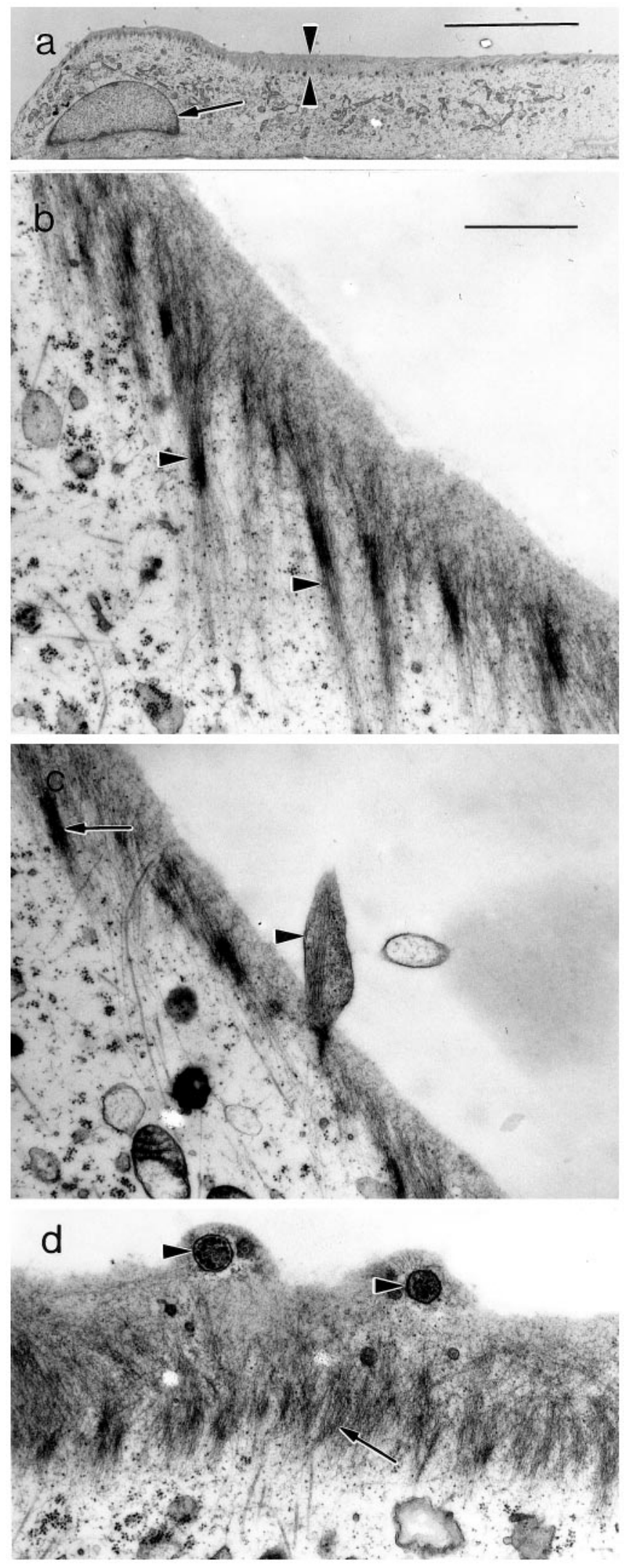

Figure 12. Cytoskeletal structures beneath the upper surfaces of cells from UB/UE-1 at $39^{\circ} \mathrm{C}$. $a$, Electron micrograph of an oblique section through a cell from UE-1 under differentiating conditions. Beneath the upper plasma membrane there is a thick cytoskeletal mesh composed of microfilaments (arrowheads). The arrow indicates the nucleus. Scale bar, tified as a calcium-activated potassium current (Rennie and Correia, 1994), whereas in mice the residual conductance has been classified as a classic delayed rectifier (Rüsch et al., 1998). Too little is known about the development, pharmacology, or molecular basis of delayed rectifier potassium currents in vestibular hair cells to judge whether the current in UB/UE-1 resembles that in neonatal, mature type II or mature type I hair cells (Rüsch et al., 1998). However, the absence of $I_{\mathrm{h}}$, a weak inward rectifier normally expressed from P3 or P4 (Rüsch et al., 1998), suggests that they are more like neonatal hair cells that may retain the competence to differentiate into either type I or type II hair cells.

An inward rectifier current was found only in a subpopulation (40\%) of cells from UB/UE-1 that expressed the delayed rectifier. Its rapid activation negative to the potassium equilibrium potential identifies the current as the classic inward rectifier $I_{\mathrm{K} 1}$. The marked decay observed at potentials negative to $-130 \mathrm{mV}$ has been described for $I_{\mathrm{K} 1}$ in vestibular neonatal and type II hair cells of various classes of vertebrates (Ohmori, 1984; Masetto et al., 1994; Holt and Eatock, 1995; Sugihara and Furukawa, 1996; Rüsch et al., 1998) and indeed in many other cell types and cloned channels (Kubo et al., 1993). In agreement with our findings in the cultured cells, $I_{\mathrm{K} 1}$ is not found in all neonatal and type II hair cells in the developing mouse utricle (Rüsch et al., 1998). A possible explanation for this is regional variation across the epithelium in the expression of $I_{\mathrm{K} 1}$ that has been reported in type II hair cells of the frog semicircular canal (Marcotti et al., 1999). Such regional variations have thus far not been studied in mammalian vestibular epithelia. Both $I_{\mathrm{K}}$ and $I_{\mathrm{K} 1}$ are likely to contribute to the resting potential, which was somewhat more negative (but not significantly so) in the cells expressing $I_{\mathrm{K} 1}$ (Table 1).

The membrane currents of the supporting-type cells were similar to those of normal vestibular supporting cells (Sugihara and Furukawa, 1996; Masetto and Correia, 1997). They were electrically similar to the cells grown at $33^{\circ} \mathrm{C}$ and showed little or no voltage-dependent ionic currents except for a weak inward and outward rectification for very negative and positive voltages, respectively.

The electrophysiology of the cell line remained remarkably consistent throughout many different experimental transitions from $33^{\circ}$ to $39^{\circ} \mathrm{C}$ and for different populations of cells thawed from frozen stocks at different times. At $33^{\circ} \mathrm{C}$ the population was clearly homogeneous, and at $39^{\circ} \mathrm{C}$ there was virtually no ambiguity in defining the three different phenotypes. With the exception of a small response in one cell, acetylcholine receptor currents were only recorded from cells that also expressed the delayed rectifier potassium current. There was also a direct correlation between this rectifier and cell size as estimated by membrane capacitance. Thus the transition to differentiating conditions activates the coherent, functional expression of a number of key hair cell genes.

The decrease in cytokeratin expression from 90 to $40 \%$ is consistent with the differentiation of approximately half the cells as hair cells. The observed increase in expression of myosin VIIa and the $\alpha 9 \mathrm{AChR}$ is also consistent with the differentiation of hair

$20 \mu \mathrm{m} . b$, The microfilament mesh was penetrated by numerous microfilament bundles (arrowheads). Scale bar, $1 \mu \mathrm{m}$. $c$, This image shows a single structure, containing a parallel bundle of microfilaments, projecting from the cell surface. Scale bar as in $b$. $d$, This image shows the microfilament mesh (arrow) and cross sections through two flagellar axonemes (arrowheads). Scale bar as in $b$. 
cells. However, we did not expect to see either Brn3.1 expressed at $33^{\circ} \mathrm{C}$ or downregulation at $39^{\circ} \mathrm{C}$. Brn3.1 is expressed as early as embryonic day 14 in the utricle, but new cells continue to be born until P6 (Sans and Chat, 1982). Although Brn3.1 is essential for continued hair cell differentiation (Erkman et al., 1996; Xiang et al., 1997), myosin VIIa is expressed transiently in the Brn3.1 null mutant, suggesting that hair cells begin to differentiate but then die (Xiang et al., 1998). In current models of cell pattern formation by lateral inhibition, differentiating hair cells are thought to inhibit adjacent cells from adopting the same fate (Adam et al., 1998; Haddon et al., 1998; Lewis et al., 1998; Lanford et al., 1999). If hair cells are lost then the inhibition may decrease, allowing new or existing neighbors to become hair cells (Stone and Rubel, 1999). Thus we might expect supporting cell lines to initiate hair cell differentiation simply as a function of dilution cloning. Proliferating cells did not reform tight intercellular junctions at $33^{\circ} \mathrm{C}$, and if the mechanism of lateral inhibition was thus blocked, then the cells may effectively have been immortalized at an early stage of hair cell differentiation. When differentiated, however, the cells formed closer contacts, and lateral inhibition may have been at least partially restored. Thus if Brn3.1 was expressed in all cells at $33^{\circ} \mathrm{C}$ but subsequently suppressed in $50 \%$ of them at $39^{\circ} \mathrm{C}$, this might explain the observed decrease in expression of Brn3.1. The implication is that cells expressing Brn3.1 are not irreversibly committed to becoming hair cells, suggesting some plasticity in the mechanism of lateral inhibition. We were unable to detect Brn3.1 in individual cells by immunofluorescence, so expression appeared to be low compared with that in our cochlear cell lines (Rivolta et al., 1998).

The cell line UB/UE-1 offers significant experimental potential toward understanding the molecular mechanisms that govern hair cell differentiation. It conditionally expresses at least three functional ion channels and several cytoskeletal proteins that characterize an early, critical stage in hair cell differentiation. These features are unlikely to be an artifact of the $\mathrm{T}$ antigen for several reasons. Not all cells at $39^{\circ} \mathrm{C}$ express the same markers, and different cell lines from the cochlea express different structural and physiological markers under the influence of the $\mathrm{T}$ antigen at $33^{\circ} \mathrm{C}$ (Rivolta et al., 1998; Jagger et al., 1999). Few cell lines differentiate fully in vitro. In previous experiments with mixed utricular cultures derived from the Immortomouse, markers for much later stages of hair cell differentiation were expressed (Holley et al., 1997). Thus it is more likely to be the culture conditions that limit hair cell differentiation in UB/UE-1 rather than an inhibitory effect of the T antigen.

Cell lines lend themselves to studies of low-abundance, cellspecific molecules. This is particularly important in the mammalian inner ear because the number of sensory cells is so small. More importantly, the conditional expression of a number of important hair cell genes in $\mathrm{UB} / \mathrm{UE}-1$ reflects the likely activation of key transcriptional processes. With an abundance of cells, the associated genes can be identified by screening with oligonucleotide (Alon et al., 1999) or cDNA arrays (Vishwanath et al., 1999). The same cells provide the means to explore the function of those genes experimentally. Such applications should make a substantial contribution to our understanding of development and potential mechanisms of therapeutic regeneration in the mammalian inner ear.

\section{REFERENCES}

Adam J, Myat A, Roux IL, Eddison M, Henrique D, Ish-Horowicz D, Lewis J (1998) Cell fate choices and the expression of Notch, Delta and Serrate homologues in the chick inner ear: parallels with Drosophila sense-organ development. Development 125:4645-4654.

Alon U, Barkai N, Notterman DA, Gish K, Ybarra S, Mack D, Levine AJ (1999) Broad patterns of gene expression revealed by clustering analysis of tumor and normal colon tissues probed by oligonucleotide arrays. Proc Natl Acad Sci USA 96:6745-6750.

Baird RA, Steyger PS, Schuff NR (1996) Mitotic and nonmitotic hair cell regeneration in the bullfrog vestibular otolith organs. Ann NY Acad Sci 781:59-70.

Barald KF, Lindberg KH, Hardiman K, Kavka AI, Lewis JE, Victor JC, Gardner CA, Poniatowski A (1997) Immortalised cell lines from embryonic avian and murine otocysts: tools for molecular studies of the developing inner ear. Int J Dev Neurosci 15:523-540.

Chardin S, Romand R (1995) Regeneration and mammalian auditory hair cells. Science 267:707-711.

Corwin JT, Cotanche DA (1988) Regeneration of sensory cells after acoustic trauma. Science 240:1772-1774.

Cotanche DA, Lee KH, Stone JS, Picard DA (1994) Hair cell regeneration in the bird cochlea following noise damage or ototoxic drug damage. Anat Embryol 189:1-18.

Elgoyhen AB, Johnson DS, Boulter J, Vetter DE, Heinemann S (1994) $\alpha 9$ : an acetylcholine receptor with novel pharmacological properties expressed in rat cochlear hair cells. Cell 79:705-715.

Erkman L, McEvilly RJ, Luo L, Ryan AK, Hooshmand F, O'Connell SM, Keithley EM, Rapaport DH, Ryan AF, Rosenfeld MG (1996) Role of transcription factors Brn-3.1 and Brn-3.2 in auditory and visual system development. Nature 381:603-606.

Fekete DM, Muthukumar S, Karagogeos D (1998) Hair cells and supporting cells share a common progenitor in the avian inner ear. J Neurosci 18:7811-7821.

Forge A, Li L, Corwin JT, Nevill G (1993) Ultrastructural evidence for hair cell regeneration in the mammalian inner ear. Science 259:1616-1619.

Forge A, Li L, Nevill G (1998) Hair cell recovery in the vestibular sensory epithelia of mature guinea pigs. J Comp Neurol 397:69-88.

Fuchs PA (1992) Ionic currents in cochlear hair cells. Prog Neurobiol 39:493-505.

Glowatzki E, Wild K, Brandle U, Fakler G, Fakler B, Zenner H-P, Ruppersberg JP (1995) Cell-specific expression of the $\alpha 9 \mathrm{n}-\mathrm{ACh}$ receptor subunit in auditory hair cells revealed by single-cell RT-PCR. Proc R Soc Lond B Biol Sci 262:141-147.

Griguer C, Kros CJ, Sans A, Lehouelleur J (1993) Potassium currents in type II vestibular hair cells isolated from the guinea-pig crista ampullaris. Pflügers Arch 425:344-352.

Haddon C, Jiang YJ, Smithers L, Lewis J (1998) Delta-Notch signalling and the patterning of sensory cell differentiation in the zebrafish ear: evidence from the mind bomb mutant. Development 125:4637-4644.

Hasson T, Gillespie PG, Garcia JA, MacDonald RB, Z hao Y, Yee AG, Mooseker MS, Corey DP. (1997) Unconventional myosins in innerear sensory epithelia. J Cell Biol 137:1287-1307.

Holley MC, Nishida Y, Grix N (1997) Conditional immortalisation of hair cells from the inner ear. Int J Dev Neurosci 15:541-552.

Holt JR, Eatock RA (1995) Inwardly rectifying currents of saccular hair cells from the leopard frog. J Neurophysiol 73:1484-1502.

Jagger DJ, Holley MC, Ashmore JF (1999) Ionic currents expressed in a cell line derived from the organ of Corti of the Immortomouse. Pflügers Arch 438:8-14.

Jat PS, Noble MD, Ataliotis P, Tanaka Y, Yannoutsos N, Larsen L, Kioussis D (1991) Direct derivation of conditionally immortal cell lines from an $\mathrm{H}-2 \mathrm{~Kb}$-tsA58 transgenic mouse. Proc Natl Acad Sci USA 88:5096-5100.

Jones JE, Corwin JT (1996) Regeneration of sensory cells after laser ablation in the lateral line system: hair cell lineage and macrophage behaviour revealed by time-lapse video microscopy. J Neurosci 16:649-662.

Kelley MW, Xu X-M, Wagner MA, Warchol ME, Corwin JT (1993) The developing organ of Corti contains retinoic acid and forms supernumerary hair cells in response to exogenous retinoic acid in culture. Development 119:1041-1053.

Kelley MW, Talreja DR, Corwin JT (1995) Replacement of hair cells after laser microbeam irradiation in cultured organs of Corti from embryonic and neonatal mice. J Neurosci 15:3013-3026.

Kubo Y, Baldwin TJ, Jan YN, Jan LY (1993) Primary structure and functional expression of a mouse inward rectifier potassium channel. Nature 362:127-132. 
Kuijpers W, Tonnaer ELGM, Peters TA, Ramaekers FCS (1992) Developmentally-regulated coexpression of vimentin and cytokeratins in the rat inner ear. Hear Res 62:1-10.

Laemmli UK (1970) Cleavage of structural proteins during the assembly of the head of bacteriophage T4. Nature 227:680-685.

Lanford PJ, Lan Y, Jiang R, Lindsell C, Weinmaster G, Gridley T, Kelley MW (1999) Notch signalling pathway mediates hair cell development in mammalian cochlea. Nat Genet 21:289-292.

Lang DG, Correia MJ (1989) Studies of solitary semicircular canal hair cells in the adult pigeon. II. Voltage-dependent ionic conductances. J Neurophysiol 62:935-945.

Lee KH, Cotanche DA (1996) Localization of the hair-cell-specific protein fimbrin during regeneration in the chicken cochlea. Audiol Neurootol 1:41-53.

Lefebvre PP, Malgrange B, Staecker H, Moonen G, Van de Water TR (1993) Retinoic acid stimulates regeneration of mammalian auditory hair cells. Science 260:692-695.

Lewis AK, Frantz GD, Carpenter DA, de Sauvage FJ, Gao W-Q (1998) Distinct expression patterns of notch family receptors and ligands during development of the mammalian inner ear. Mech Dev 78:159-163.

Marcotti W, Russo G, Prigioni I (1999) Position-dependent expression of inwardly rectifying $\mathrm{K}^{+}$currents by hair cells of frog semicircular canals. NeuroReport 10:601-606.

Masetto S, Correia MJ (1997) Electrophysiological properties of vestibular sensory and supporting cells in the labyrinth slice before and during regeneration. J Neurophysiol 78:1913-1927.

Masetto S, Russo G, Prigioni I (1994) Differential expression of potassium currents by hair cells in thin slices of frog crista ampullaris. J Neurophysiol 72:443-455.

Nishida Y, Rivolta MN, Holley MC (1998) Timed markers for the differentiation of the cuticular plate and stereocilia in hair cells from the mouse inner ear. J Comp Neurol 395:18-28.

Ohmori H (1984) Studies of ionic currents in the isolated vestibular hair cells of the chick. J Physiol (Lond) 350:561-581.

Presson JC (1994) Immunocytochemical reactivities of precursor cells and their progeny in the ear of a cichlid fish. Hear Res 80:1-9.

Presson JC, Popper AN (1990) Possible precursors to new hair cells, support cells, and Schwann cells in the ear of post-embryonic fish. Hear Res 46:9-21.

Rennie KJ, Correia MJ (1994) Potassium currents in mammalian and avian isolated type I semicircular canal hair cells. J Neurophysiol 71:317-329.

Ritchie AK (1987) Two distinct calcium-activated potassium currents in a rat anterior pituitary cell line. J Physiol (Lond) 385:591-609.
Rivolta MN, Grix N, Lawlor P, Ashmore JF, Jagger DJ, Holley MC (1998) Auditory hair cell progenitors immortalised from the mammalian inner ear. Proc R Soc Lond B Biol Sci 265:1595-1603.

Rüsch A, Eatock RA (1996) A delayed rectifier conductance in type I hair cells of the mouse utricle. J Neurophysiol 76:995-1004.

Rüsch A, Lysakowski A, Eatock RA (1998) Postnatal development of type I and type II hair cells in the mouse utricle: acquisition of voltage-gated conductances and differentiated morphology. J Neurosci 18:7474-7486.

Ryals BM, Rubel EW (1988) Hair cell regeneration after acoustic trauma in adult Coturnix quail. Science 240:1774-1776.

Saffer LD, Gu R, Corwin JT (1996) An RT-PCR analysis of mRNA for growth factor receptors in damaged and control sensory epithelia of rat utricles. Hear Res 94:14-23.

Sans A, Chat M (1982) Analysis of temporal and spatial patterns of rat vestibular hair cell differentiation by tritiated thymidine radioautography. J Comp Neurol 206:1-8.

Slepecky N (1996) Structure of the mammalian cochlea. In: Handbook of auditory research, Vol VIII, The cochlea (Dallos P, Popper AN, Fay RR, eds), pp 44-129. New York: Springer.

Stone JS, Oesterle EC, Rubel EW (1998) Recent insights into regeneration of auditory and vestibular hair cells. Curr Opin Neurol 11:17-24.

Stone SW, Rubel E (1999) Delta1 expression during avian hair cell regeneration. Development 126:961-973.

Sugihara I, Furukawa T (1996) Inwardly rectifying currents in hair cells and supporting cells in the goldfish sacculus. J Physiol (Lond) 495:665-679.

Vishwanath RI, Eisen MB, Ross DT, Schuler G, Moore T, Lee JCF, Trent JM, Staudt LM, Hudson Jr J, Boguski MS, Lashkari D, Shalon D, Botstein D, Brown PO (1999) The transcriptional programme in the response of human fibroblasts to serum. Science 283:83-87.

Warchol ME, Lambert PR, Goldstein BJ, Forge A, Corwin JT (1993) Regenerative proliferation in inner ear sensory epithelia from adult guinea pigs and humans. Science 259:1619-1622.

Xiang M, Gan L, Daqing L, Chen Z-Y, Zhou L, O'Malley Jr BW, Klein W, Nathans J (1997) Essential role of POU-Domain factors Brn3c in auditory and vestibular cell development. Proc Natl Acad Sci USA 94:9445-9450.

Xiang M, Gao W-Q, Hasson T, Shin JJ (1998) Requirement for brn-3c in maturation and survival, but not in fate determination of inner ear hair cells. Development 125:3935-3946.

Zheng JL, Lewis AK, Gao W-Q (1998) Establishment of conditionally immortalized rat utricular epithelia cell lines using a retrovirusmediated gene transfer technique. Hear Res 117:13-23. 